A major purpose of the Technical Information Center is to provide the broadest dissemination possible of information contained in DOE's Research and Development Reports to business, industry, the academic community, and federal, state and local governments.

Although a small portion of this report is not reproducible, it is being made available to expedite the availability of information on the research discussed herein.

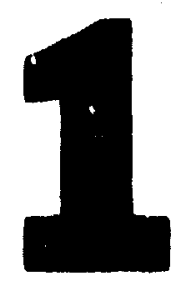




\section{AL-UR $-85-2964$}

$\because$

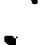

$\operatorname{coNF}-8508119--1$

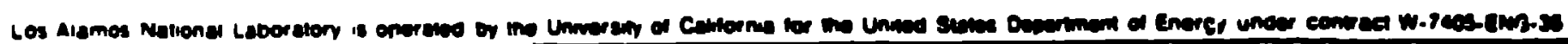

$L A-U R--85-2964$

DE85 017543

TITLE COHERENT AND SPONTANEOUS RAMAN SPECTROSCOPY

IN SHOCKED AND UNSHOCKED LIQUIDS

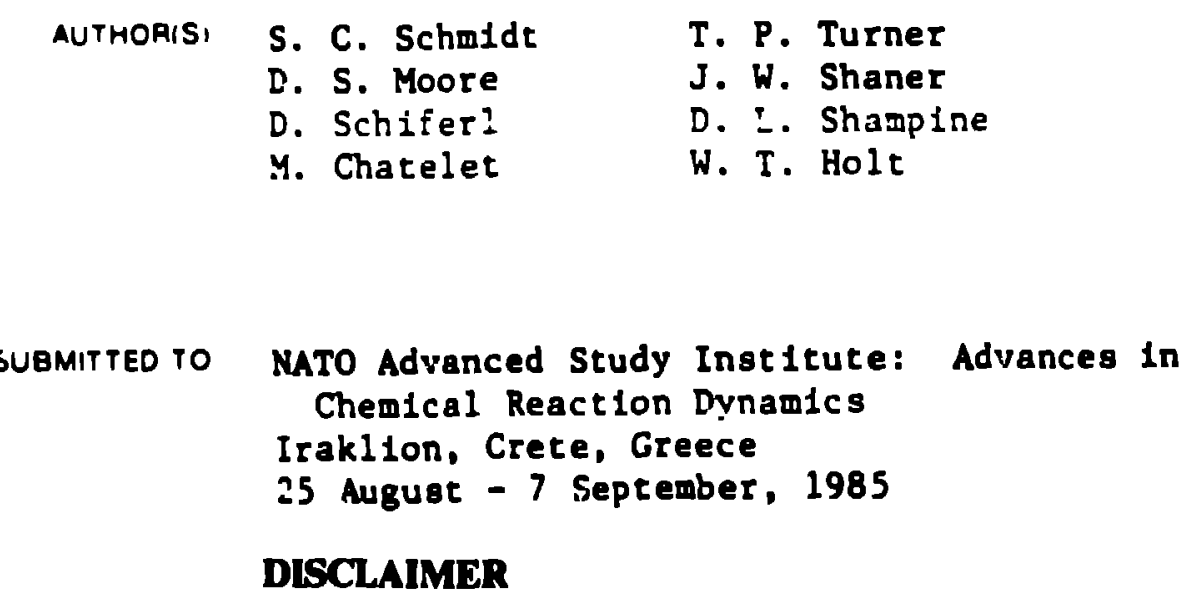

This report we propared a an eccount of work aponeored by an acency of the United States Dovornmeat. Neither two United States Goverament nor any apeosy thereof, nor ay of thetr employecen, makes asy warranty, exprew or tropliod, or anumes any leapl liablity or reaponatbithy for the aceuracy, completenem, or usoruleese of any information, apparatue, produce, or

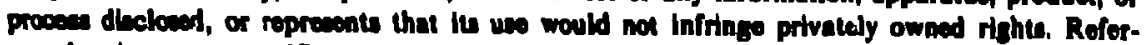

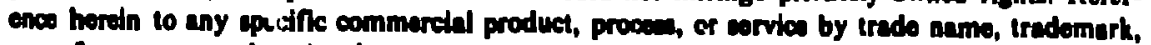

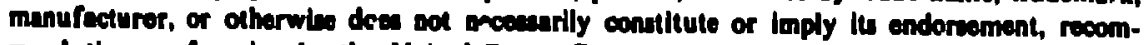
mendation, or favoring by the Usiled State Covernmeat or any acency therenf. The viows

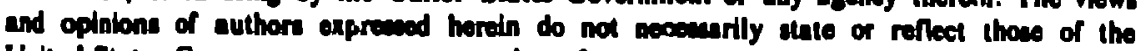
Untiod States Government or any eqeancy thereof.

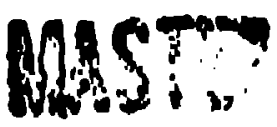

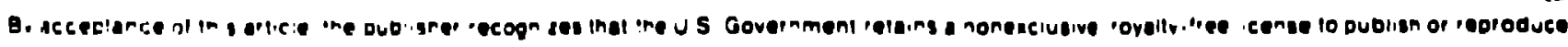

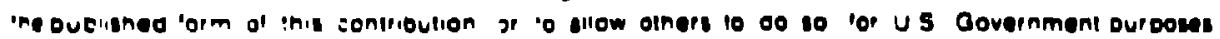

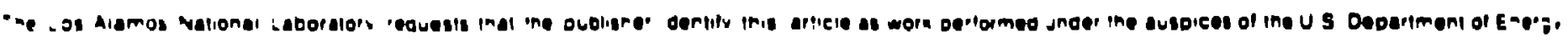
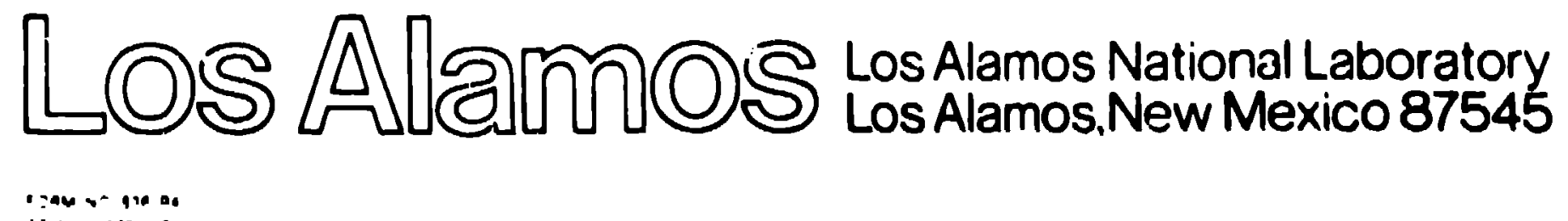
S. C. Schaldt, D. S. Moore, D. Schiferl, M. Chatelet, T. Turner, J. V. Shaner,
D. L. Shanpine, and Y. T. Bolt University of Celifornie Los Alenos National Laboratory P. 0. Box 1663

Los Alanos, Nev Mexico 87545, USA

Coherent and non-coherent Raman spectroscopy is being used to study the structure and energy transfer In nolecular liquids at high pressures. Stinulated Raman scattering, coherent anti-Stokes Raman scatterIng, and Raman induced Rerz effect scaltering measurements have been performeo in liquid benzene and liquid nitromethane shocked to pressures up to $11 \mathrm{GPa}$. Frequency shifts vere observed for the $992 \mathrm{~cm}^{-1} \mathrm{ring}$ stretching mode of benzene and the $920 \mathrm{~cm}^{-1} \mathrm{CN}$ stretching aode of nitromethane. Results of these dynamic experlments are compared to spontaneous Raman scattering measurements made in a high tenperature diamond anvil cell. Also, a plcosecond infrared pump/spontaneous ant1-Stokes Raman probe experiment is being used to measure $\mathrm{CB}$ stretch vibrational relaxation times in liquid halogenated methanes statically compressed to a fev tentiss GPa.

Fork supported by the United States Departaent of Energy. 
I. INTRODUCTION AND OBJECTIVES

Presently most models of explosive and shock induced chealcal behavior treat the mediut as a continuum 1,2 that chemically racts according to either a pressure dependent or Arrhenius kinetics rate lav. One or more parameters are used to incorporate the globa? chosical behavior, hydrodynamic phenomenology and effects of material heterogene1ty. In the past few years, several studtes ${ }^{3-10}$ have been started that attempt to 1mprove the methodology by defining the continuum, not as a single component, but as one that incorporates ideas such as hot spots, voids or multicomponents. Bowever, in all of these studies essentially no effort is made to incorporate any of the microscopic detalls of the shock-compression/energy transfer and release phenomenology that const 1tutes the detonation or reactive process.

Ideally, for descriptions of reactive processes, we would like to treat the continuum as a mixture of pure components and incorporate changes in iiolecular structure resulting from shock comrcessicn, disequlibria due to shock compression, energy transfer from the hydrodynamic mode into the molecular internal degrees of freedow and the subsequent microscopic reaction history, enerby relesse, and product formation. While such a goal may appear overly ambitlous ve feel that by using some of the diagnostlc., particularly fast optical techniques, that have become avallable in the past tew years, progrsss can be made toward understanding certain fasets of this objective. For example, spontaneous Ramen spectroscopy has already been used to make temperature estimates of shocked explosives ${ }^{11-13}$ and examine the structure of shock-compressed matertals. ${ }^{14-15}$ In our own work, coherent Rainan scattering techniques have been used to measure vibrational frequency shifts in benzane and nitromethane shock-compressed to pressures just below those where chem1cal reaction is expected. ${ }^{16-22}$ Intial indications suggest the prospects for extending these measurements into the pressure reglons where cherical reaction occurs are good. 
Pigure ! depicts sone of the consequences of the shick-conpression of eolecular aterials. In addition to the acroscoplc continuw effects expected (a.8. hydrodynante flov, density and teaperature increases), alecular systeas, because of vibrational and electronic energy levels that possibly lie close to the ground state, are expected to readily undergo a shock induced transfer of energy to these internal degrees of freadon. Under shock-conpresston, the nolecular structure and hence the intranolecular and intermolecular forces will be altered considerably, consequently the energy transfer rates and mechanisas ay be dramatically different fron those expected on the basis of either extrapolation from abilent conditions or thermodynamic equilitrium. Depending or the vibrational and electronic relaxation rates and mechanisas in the high density/high temperature fluid, the exclted states could have a nonequilibrium population density. Different authors $23-25$ have proposed different initial steps for the chemical reaction schemes in detonating explosivas. Bovever, definitive supporting experiments have not been performed. The ensuing microscopic chemical reactions involving energy release and product formation also require experimental study.

The objective of our vork has been two folo; (1) to determine the noleculat structure and identify chemical species in unreacting and reacting shock-compressed molecular systems and (2) to study the effect of pressure and temperature on condensed phase energy transfer. Also, ve would like to identify the unique feature of a shock vave vhich contribte to the energy transfer piocesses. Achievement of these goals vould contribute sientificantly to understanding the infilal mecianisas governing shock-induced chemlcally reacting molecular systems and possibly to the steps controlling product formation. Tvo experitents are being eaployed in the pursult of these objectives. A tvo-stage light gas gun is baing used to dynamically stixck-compress moiucular liquids to pressures where chemical reaction occurs. The high density/high temperature fluid is then probed ising coherent Ranan scattering techniques. In the second effort which is still in the construction phase, a plcosecond puap/spontaneous anti-Stokes Raman scattering probe experiment will be used to aeasure vibrational relexation rates in liquids statically conpressed uning high pressure cells. 
II. EXPERIMENTAL CONSIDERATIONS

Prior to discussing our experiantal studies and results to date, several probleas associated with conductins condensed-phase shock-vave experiments will be revieved. These difficulties have historically lialted the ability to conduct exparinents lin the advarae conditions through and ianediately behind the shock-front and for our studias strongly governed the experinental techniques used.

For many materials shock vaves are belleved to be of the order of $1 \mathrm{um}$ or less in tnickness. ${ }^{26-28}$ The passage time through the front of a $1 \mathrm{\mu m}$-thick shock whose velocity is $5 \mathrm{~km} / \mathrm{s}$ is thus of the order of $200 \mathrm{ps}$ or less. Hence, if ve desire to temporally and apatially resolve a measurement through a shock-front (5 data points), the diagnostlc technique selected must be capable of spatial and temporal resolutions of $0.2 \mathrm{\mu m}$ and $40 \mathrm{ps}$, respectively. Condensed-phase chemical reaction tiaes could be of the order of 1 ps, thus necessitating even better temporal resolution. Bowever, if all that is desired is to resolve features in the few mon long region behind the shock-front where relaxation and reaction processes may occur, then these requirements are drastically reduced.

Optical techniques offer some potential for achleving measuraments within these stated Iimications. Bovever, with such nothods some additional compilcations arise. Many materials are opaque or besome opaque when shock-compressed. Consequently, the use of opifical diagnostic techniques is liofted to a fev select materinls primarily for phenomenoiogical studies. Such studies may, however, have tramendous potential when used in conjunction with other techniques for determining phenomenclogy of shock-compressed materials. Tro other difficulties inherent in optical shock-vave diagnostlc techniques are the changes in material refractive index thut accompany the density changes characteristic of shock waves and the possibility of photochemistry induced by the optical probas. Pigure 2 shous the path deviation that rccurs vhen an optical beam is passed through a hypothetlcal shock-coupressed nystem. The tralling shock weve near the sample boundarles tends to bend the optical beam avay from the shock-front thus aking prediction of the 
expected optical path difficult. Any shock-front curvature vill conpound this diffirulty. If the shock velocity in the vindous is greater than in the sample, additional conplications could arise fron the effect of the core conplex vave structure on vindov transaission. Many nolacules undergo photochendical reactions when exposed to light, partlcularly that in the ultraviolet region of the spectrun. If these reactions are fast conpared to the characteristic tine of the optical diagnostic, masurements could Include the effects of both the shock stinulus and the photochemical reaction.

Measurements made using inhomogeneous samples often are averages over the nonuniformities and consequently do not reflect the details of the microstructure. For materials like granular explosives, the inhonogeneous nature is readily apparent and expertaents are interpreted accordingly. For samples thought io be honogeneous, ambigutties san arise. For example, Fig. 3 depicts two image-intensifier-camera pictures ${ }^{29}$ of the shock-front of detonating nitromethane and an $80 \%$ nitrumethane/20\% acetone mixture. These pictures show that microstructure exists in the vicinity of the shock front even in liquids, which are of ten thought to be homogeneous. Also, nothing is known about microstructure in the region immediately behind the shock front. When performing experiments on nitromethane or simflar substances, espectally experiments utilizing optical techniques where a spatial resolution of tens of eicrons is desired, one must be aware that results may actually reflect an avorage over smaller characterisil: microstructure. Conversely, a single measurement with spatial resolution smaller than the microstructure may be alsinterpreted as representative of the average material.

Shock recovery experiments are often used to observe chemical and physical changes through and limmediately behird the shock-front. Bovover, these changes occur not only in the high pressure and tamperature regtion at the shock front, but aiso in the somevhat lover pressures and temperatures of the expansior. region. The inabillty to separate these two effects makes the interpretation of these experiments difficult. 
III. COHERENT RAMAN SCATTERING IN SBOCK-COMPRESSED LIOUIDS

Three coherent Ranan scattering techniques have been atteapted in shock coapressed liquid samples. Advantages of these techniques, primarily because of large scattering intensities and the bean-like nature of the scattered signal, are increased detection sensitivity, teaporal resolution lints approaching leser pulse iengths, isd possible spatial resolution approaching the diffraction linit of the ontical conponents. As with all optical ne-hods in shock-vave applications, optical accessibility because of material opacity or particulate scattering remains a rajor difficulty vith coherent Raman scattering.

Backward-stimulated Raman scattering (BSRS) has been observed in shock-compressed benzene up to pressures of 1.2 GPa. 17 Stimulated Raman scattering 30,31 (Fig. 4) occurs when the incident laser intensity in a medium exceeds a threshold level and generates a strong, stimulated Stokes beam. The threshold levei is determined by the Raman cross-section and linewidth of the transition and by the focusing parameters of the incident beam. Typical threshold irtensities are $-10-100 \mathrm{GV} / \mathrm{cm}^{2}$. Plgure 5 iilustrates the arrangement used for the backward stimiated Raman scattering experiment. An aluminum projectile oi known velocity from a 51-mm-dian, 3.3-m-iong gas gun impacted an aluminum target plate producing a shock wave which ran forvard into a 7.5 to 8 -no-thick reagent grade benzene sample (Mallickrodt, Inc.). Standard data reduction techniques ${ }^{32}$ using published shock-velocity/particle-velocity dara ${ }^{33}$ vere used to determine the state of the shock-compressed benzene. Experiment design was greatly facilitated using the MACRAME one-dimensional-vave propagation computer code. 34

A singit 6-ns-long frequency-doubled Nd-doped ytrium aluminum garnet (Nd:YAG) laser pulse vas tocused using a 150-mm focal length lens thiough the quartiz window to a point in the benzene 2 to $6 \mathrm{~mm}$ in front of the rear sample vall. The high intensity of the laser at the focus, coupled with the preserice of a large cross-section Raman active vibratlonal node in the ample, produces gain in the forward and backvaid direcitons along the beaw at a frequency that is different fron the 
Mitac frequency by the frequency of the active node. The tialns sequence vas deteralned by the inconing projectile. Interruption of a Deve laser bean, In conjunction vith an appropriate tiwe delay, tricrered the laser flash lanp approxiantely 300 us prior to inpact. A tiee-of-arrival pin astivated just before inpact and the appropriate time delay served to O-sultch the laser fust prior to the shock vave striking the quartz vindov and after 1 t vas past the focal point of the Incident laser 11ght.

In liquid benzene, the $v_{1}$ syametric stretching sode 35 at $992 \mathrm{~cm}^{-1}$ has the lowest threshold for stinulated Raman scattering inducad by 532-ne light, and vas the transition observed in these experinents. As depicted in Pig. 5, the backward stinulated Raman bean vas separated fron the incident laser by means of a dirhroic filter and vas then focused onto the 10-un-vide entrance slit of a 1-w Czerny-Turner spectrograph equipped with a 1200-grooves/nm grating blazed at $500 \mathrm{~nm}$ and used in first order. Figure 6 shows the resulting spectrogram for benzene shock-compressed to $0.92 \mathrm{GPa}$. The reflected Incident laser line and the backward stimulated Brillouin-scattering line at $532 \mathrm{~nm}$ are observable, as are the backvard stimulated Raman-scattering line fron amblent benzene. The latter feature resulted as a consequence of the shock vave having passed only about tro-thirds of the way through the sample, and hence a stimulated Raman signaj. vas also obtained fron the unshocked liquid.

The frequency shift of the Raman line has saall contributions of approximately $0.1 \mathrm{~cm}^{-1}$ because the light crosses the moving interface betveen two madia of different refractive indices and because of the material notion behind the shock vave. ${ }^{36}$ since these errors are considerably less than the experimental uncertainty of $\pm 0.5 \mathrm{~cm}^{-1}$ for the measured frequency shifts and are a small fraction of the shift due to compession, no attenpt uns aade to correct the data for these offects.

Plgure 7 gives the measured shift of the $v_{1}$ ring-stretching mode vibrational vevenuaber versus pressure ot $1 \mathrm{l}$. shocked benzene. Observation of the ring-stretching mode at $1.2 \mathrm{GPa}$ strongly sugesets that 
-9-

benzene molecules still exist several allileters behind the shock vave at this presiure, but does net, hovever, exclude sone decongert1on. $27,37,38$

Also depicted in Fig. 7 is the ring-stretching node vibrational wavenuber shift measured for benzene isotheraally coapressed at temperatures between $24^{\circ} \mathrm{C}$ and $209^{\circ} \mathrm{C}$ with a dianond-anvil cell and techniques previously described. ${ }^{39}$ Measurements of the phonon spectrun in the region $40-200 \mathrm{~cm}^{-1}$ vere used to alstinguigh betveen benzene $I$, benzene II, and liquid benzene. The vibrational frequencles obtained from spontaneous-Raman-scattering measurements at $24^{\circ} \mathrm{C}$ with use of the 568.2-nm line of a krypton laser agree vell vith previous results for benzene. 35

At fixed pressure, no temperature shift vas observed in these static measurements. The wavenumber shifts for the dynamic experinents agree vell with the static data for either liquid benzene or benzene II, but differ substantially frow those for benzene $I$. At pressures belov the I-II-ilquid triple point near $1.2 \mathrm{GPa}, 40,41$ the shocked benzene is therefore probably at temperatures high enough for it to be in the liquid state. At pressures near $1.2 \mathrm{GPa}$, the shock-compressed material could be either liquid or benzene II since both phases exhibit about the same magnitude of wavenumber shift for the ring-etretching mode, and the Bugoniot lies close to the phase boundary.

Beam intensities using BSRS are sufficiently large that film can be used as $a$ detector. The large incident intensities required, hovever, can cause damage to optical components near focal points. Spatibl and temporal resolution are determined by the confocal parameter of the focusing lens and the incident laser pulse duration. The BSRS technique also suffors because only certain molecules produce stimulated Raman scattering and of those molecules only the lovest threshold transition can be observed. Because of these lluttations other coherent Raman scattering processes affording wore experimental flexibility vere attempted. 
$-10-$

Coherent anti-Stokes Ranan scateering (CARS) ${ }^{4-45}$ (Pig. 4) occurs as four-vave peranetric process in which three vaves, two at a pup frequency, $\omega_{p}$, and one at a stokes frequency, $\omega_{g}$, are alied in a sanple to produce a coherant bean at the ant1-Stokes frequency, $\omega_{\mathrm{az}}=2 \omega_{\mathrm{p}}-\omega_{\mathrm{g}}$. The efficiency of this axing is greatly enhanced if the frequency difference $\omega_{p}-\omega_{s}$ coincides vith the frequency of a Ranan active node of the sanple. An advantage of CARS is that $1 t$ can be generated at incident pover levels considerably belov those required for stinulated Raman scattering. Bnwever, since phase watching is required, possible geonetrical arrangements are linited.

A schematic of the experimental apparatus used to perform reflected brcadband coherent anti-stokes Raman scattering (RBBCARS) in shock-compressed benzene and nitromethane is shom in Pig. B. Por pressures greater than $2 \mathrm{GPa}$, a two-stage light gas gun vas used to accelerate a polycarbonate projectile vith 4-mm-ihick A231B magnesium or 2024 aluminum impactors to a desired velocity. The projectile struck an approximately 2.4-m-thick 304-stairiless-steel target plate producing a shock vave which ran forvard into a $2.7-\mathrm{mm}$ to 3.3 -mm-thick benzene (or nitromethane) sample. Lowar pressures vere achleved using the previousiy described technique for backward stimulated Raman scattering. Stainless steel vas chosen as the target plate besause of previous experience and a series of reflectivity measurements which shoved that polished steel vould retain approximately 20 percent of its original reflectivity under shock compression at 11 GFa in the liquid sample (approximately $70 \mathrm{GPa}$ in the stainless steel). This was necessiry to reflect the CARS stznal back out of the shoik-compressed liquid. Reagent grade benzene (Mallinckrodt, Inc.) and commercial grade (Angus Chemical Co.) nitromethane vere used. The state of the shock compressed material vas deterained as described above.

The timing sequence for the RBBCiRs experiment was detertined by the incoming projectile. A signal from three BeNe laser/photodiode detectors located in the bartel approximately $2.8,1.2$ and 0.7 . from the target, in confunction with an appropriate tive delay, triggered the laser flash lanps approxiately 300 us prior to lapart. A tine-of-errival pin act1- 
$-11-$

veted fust after the shock entared the liquid and another tiew delay served to 0-suitch the laser approxinately when the shocik vave arrivad at the quartz vindow.

Since the Ranan frequencies of the shock-coupressed aterials are not precisely knovn, and since ve vish to produce CARS sigmals fzon nore than one aode or species, a broadband dye laser, with banduidth equivalent to the gain profile oi the dye, vas used as the stokes bean. ${ }^{46} A$ portion of the 6-ns-long frequency-joubled Nd: YAG laser pulse vas used to pump the dye laser. The dye laser beam vas passed through a Galilean telescope and sent along a path parallel to the remaining pump laser tovards the sample. The beams vere focused and crossed ( $v$ th approximately 1 -mm length of overlap) at a point approxicately 1 in in front of the windor using a previously described technique. ${ }^{47}$ The beam crossing angle (phase-matching angle) vas tuned by adjusting the distance between the parallel beans using a turning mirror on the pump laser beam. The CARS beam was reflected out of the shocked sample by the highly polished front surface of the target plate and along a paih parallel to the two incoming beams. After being separated from the pump and stokes beams using a long-wavelength-pass dichroic filter, the bean vas focused onto the $100 \mu \mathrm{m}-v i d e$ entrance slit of a $1-m$ spectrometer equipped $u$ th a $12001 / \mathrm{mm}$ grating blazed at $500 \mathrm{~nm}$ and used in first order. The signals vere detected at the exit of the spectrometer using an intensified diode array (Tracor Northern Model TN-6133) coupled to an optisal nultichannel analyzer (OMA) (Tracor Northern Model TN-1710). The instrument spectral resolution was approximately $4.2 \mathrm{~cm}^{-1}$.

Figure 9 shous the OMA recorded RBBCARS signals for the ring-stretching mode of benzene at pressures from ambient to $10.6 \mathrm{GPa}$ (approximately $1000^{\circ} \mathrm{K}$ ). 48 Spectral positions were measured relative to the 253.652-nm $8 g$ emission line in secund order.

A preituinary analysis of the spectral lines vas performed using: 44

$$
I_{\text {as }} \alpha \operatorname{sos}_{\text {as }}^{2}\left|x^{(3)}\right|^{2} I_{s}
$$


where $I_{a s}$ and $I_{s}$ are the Intensities of the anti-stokes and Stokes beans resper:tively. For this calculation, $I_{s}$ was chosen to be Gaussian that approxinately fit the broad band dye laser profile. In future experinents, because of shot-to-shot variations and notse in tis dye lager profile, a spectrographic record will be wade of the profile for each shot and used directly to calculate the synthetic spectrn. The third order susceptibility, $x^{(3)}$, is given by

$$
x^{(3)}=x_{N R}+\sum_{j} x_{j}^{\prime}+1 \sum_{j} x_{j}^{n}
$$

where $x_{Y_{R}}$ is the contribution from the noridesonant background and $j$ is the aum over spectral lines. The real, $x_{j}^{\prime}$, and 1maginary, $x_{j}^{\prime \prime}$, parts of the CARS susceptibility are

$$
x_{j}^{\prime}=\frac{\Gamma_{j} x_{j}\left(w_{j}-w_{p}+w_{s}\right)}{\left(w_{j}-\omega_{p}+\omega_{s}\right)^{2}+\Gamma_{j}^{2}}
$$

and

$$
x_{f}^{\prime \prime}=\frac{\Gamma_{j}^{2} x_{j}}{\left(\omega_{j}-\omega_{p}+\omega_{s}\right)^{2}+\Gamma_{j}^{2}}
$$

respectively. $\omega_{j}, \Gamma_{j}$ and $X_{f}$ are the freyiency, half amplitude half vidth (घVIM) and the peak amplitude of the corresponding spontaneous Raman acattered line. Por this vork no attempt vas ade to dertve population denaitles (or temperatures) from $X_{f}$ using known Raman cross-sections. In fact, it may be necessary to re-determine the Raman cross-sections for the high densities characteristic of shock-compression.

Figure 10 deplets the experimentally measured and calculated spectra for the benzene ring atretching mode at $7.4 \mathrm{GPa}$. The intensty of both epectre has been normalized to a peak amplitude of 0.95 . The etructural 
features that appear in the neasured spectra are thought to result fron the notse in the broad band dye laser. An initial analyols of the apactral shape at $10.6 \mathrm{GPC}$ is dramatically different and cequires tvo spactral lines to fit the measured profile. This vill be discussed in a future publication.

The frequency shifts estinated for the 7.4 GPa line and the lines at other pressurcs are depicted in $81 \mathrm{~g} .7$ along vith the frequency shifts deterained from BSRS measureaents discussed previously. The rasults show an initial linear change of the frequency shift with pressure and then a veakening of this dependence as the region near $13 \mathrm{GPa}$ is approached. Previous vork $27,37,38,49,50$ suggests chenical reaction occurs at these pressures. A plot of frequency shift versus volume change shows a nonIInear dependence at all pressures.

The RBBCARS spectra for the CN stretching mode of nitromethane at pressures from ambient to $7.6 \mathrm{GPa}$ (approximately $9500^{\circ}$ ) 51 are shown in Fig. 11. The existence of the $C N$ mode at microsecond times after shocking implies that decomposition of the nitromethane has not occucred as has been observed for times of tens of microseconds ${ }^{52}$ and in static high temperature/high pressure studies. 53 Measurenents are presently being extended to higher prossures where nitromethane is thought to be reactive for very short shock run distances. 12, 18,54-56

Synthetic spectra vere obtained for the nitromethane CN stretch node using the procedure previously described for benzene. Figure 12 shows the experimentally measured and calculated spectra for 5.5 GPa normalized to peak intensity of 0.95 . At $5.5 \mathrm{GPa}$ and for the lover pressure nitronethane spectra, this preliminary analysis suggests that the spectral signatures are much better matched using tro spectral ines separated by approximately $10 \mathrm{~cm}^{-1}$. This second line has been observed previously in static high pressure Raman spectra. 57 The fitting at $7.6 \mathrm{GPa}$ required a miniaun of four or five spectral lines to represent the measured data. Discussion of these results will be vithheld for a future publication when aore accurate synthetic spectro can be calculated using measured dye leser proftles. 
Pigure 13 shows the eatinates for the Raan frequency shifts of the core Intense spectral feature versus pressure uaing the analyats Indicated above. Also depicted are the frequency shifts measured for the CN stretch aode of solid nitronethane using a dianond anvil high pressure cell ${ }^{58}$ and the spontaneous Raman measurements for initronethane shocked to pressures of i GPa.12 It is noted that our results obtained for the shock-compressed material do not differ significantly from the Raman shifts obtained for solid nitromethane. At present, ve do not have on explanation for the difference between our results and those obtained by Delpeuch and Menil'12 using spontaneous Raman scattering. Barlier results ${ }^{11}$ by these authors agreac oore closely with our results. The plot of frequency shift versus volume change vas very siallar to that observed for benzene.

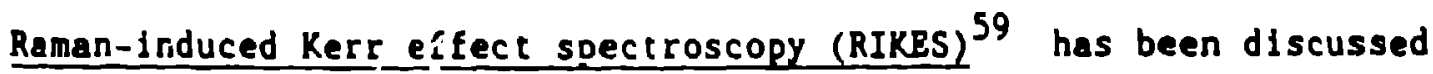
as diagnositic technique $19,20,00$ for performing measurements in shock-compressed systems which may have a large non-resonant background. RIKES requires a single frequency pump beam, a broad-bend probe source, no phase watching and iover incident power levels than stimulated kaman scattering (Pig. 4).

The effect can be described in terms sintlar to the above descripiton of CARS. A Ilnearly polarized probe laser bean is passed through the rotating electric field of a circularly polarized pump beam. The four-wave parametric process described above Induces an ellipticity on the probe beam whenever the frequency difference between the two lasers -quals that of a Raman active transition in the sample. 61,62 since the rIKES involves the use of a single frequency pump laser and a broadband Stokes laser, it can be performed with an apparatus very sidilar to the above described RBBCARS apparatus. The modifications necessary are shown In Fig. 14 and are described below. The poition of the frequency-doubled Nd:Yag laser beam that does not punp the dye laser is passed through a Presnel thoab to produce a benm of $>99 x$ circular polarizetion. The dye laser beau (stokes frequencies) is passed through a high quality Glan-Taylor (ati-gap) prise to produce a bean of - 1 part in $10^{6}$ linear polarisation. The tro beaws are focused and crossed in the sapple using 
- 150 wocal length, 50 an dianoter lens. The crossing angle 18 near 6 degrees, giving an overlap length of -150 ue at the fosus. The stakes bean is then reflected by the highly pollshed front surface of the target plete back through the sanple and along a path parallel to the incoalng beans. A alrror separe:es the reflected dye laser bean fron the other beans and directs it first through a Bablnet-sollel polarisation compensator and then through a Gnn-Taylor polarization analyser. The compensator vas found to be necessary to renove the ellipticlty introduced into the lineurly polarized stokes laser bean by the birefingence inherent in the optical conponents locaied betveen the polarizers, including the ambient sample. When the two Glen-Taylor prisus are crossed, the dye laser beam is blocked except at frequencles corresponding to Ramen resonances, where the RIKES signals are passed. These signals are directed through a dove prism, focused into the entrance slits of the 1 ospectrometer and detected by the oma systoa.

Figure 15 shows two RIKES $992 \mathrm{~cm}^{-1}$ region spectra of benzene shock-compressed to $1.17 \mathrm{GPa}$. Both traces have spectral features, hovever they are not consistent and do not exhibit the pressuru-induced frequency shift expected for the benzene ring stretching aode based on previous BSRS and RHBCARS experiments. In a polarization sensitive coherent Raman experiment, such as RIKES, the possibility exists that shock-induced changes in a waterial vould perturb the prohe laser polar1zation sufficiently to obscure the desired signals. Therafore, the sansitivity of the RIKES apparatus to minor rotations of the dye laser polarization vas investigated. The figure of mertt used vas the polariaation analyzer rotation angle necessary to saturate the detector vith unblocked dye laser. It was found that the detector could be driven from zero signal to saturation with a polarization rotation angle of - 20 arc winutes (20') (using $50 \mu \mathrm{m}$ slits and $50 \mathrm{\mu J}$ dye laser energy). The RIKES signal found for the ring-stretching mode of amblent liquid benzene nearly saturated the detector through $25 \mu \mathrm{\mu m}$ slits (using - $200 \mathrm{uJ}$ punp laser energy and $6^{\circ}$ bean crossing angle). These data suggest that, if the shock-compressed sample induced a rotation of the probe laser polartzation $220^{\prime}$, the signal vould be masked by the brosd dye laser background passed by the analyzer. The RIKES spactra (FIg. 15) obtalned in shocked 
sanples shoy only broadband dye laser which has been passed by the polar1zation analyzer. These results indicate that the shock-compressed sample induces a rotation of at least $20^{\prime}$ on the dye laser polarization. They also lead to the conclusion that, while it way be possible to perforw RIKES experiments in shock-compressed waterlals in spite of our fallure, the experiment is considerably more difficult than techniques not sensitive to the absolute polarization of the laser beam (such as BSRS and RBBCARS).

\section{ENERGY TRANSFER IN HIGB PRESSURE LIQUIDS}

Although an abundance of literature ${ }^{63-80}$ exists describing condensed phase energy transfer and relaxation phenomenology at ambient pressures and various temperatures, there is a dearth of studies showing behavior as a result of high pressure, ${ }^{81-83}$ of large stress gradients, and of temperatures typical in shock-vave environments. Since understanding condensed phase molecular energy transfer is fundamental to understanding shock-irduced chenfcal reactions and detonation, we have inftiated an experiment to study the effects of pressure and telaperature on condensed phase energy transfer. The experinent is based on the picosecond relaxation experlments of Laubereau ot $a .84,85$ and Fend $t$ et 1.86 and ultrasonic studies of Takag1 et al. 74,75 which study the vibrational energy transfer in substituted methanes. These materlals were chosen because they have a simple molecular structure and have relaxation times comparable to those expected in shock compressed hydrocarbons. The lower vibrational energy levels and sor. overtone and combination levels in the vicintty of the $\mathrm{CH}$ stretch levels near $3000 \mathrm{~cm}^{-1}$ are shown in Fig. 16 for dichloromethane, dibromomethane and dilodomethane. The results of the studies for dichloromethane show that after populating the $\mathrm{CH}$ stretch modes using a picosecond infrared laser pulse (equilibration between tne two modes is very rapld) these levels decay through a weak Ferm1 resonance to an overtone level of the bending modes. The presence of the Formi resonance is deduced from a line in the infrared spectruin at $2832 \mathrm{~cm}^{-1}$ due to the first overtone of the $v_{2}$ bending mocie (F1g. 16). $v_{1}$ and $v_{6}$ are the two $\mathrm{CH}$ stretching modes and the peak at $2832 \mathrm{~cm}^{-1}$ is from $2 v_{2}$. We believe that an Important aspect of energy transfer during shock 
compression and shock-conpression chentstry is hov the enercy flows through the vibrational degrees of freadon, 1.e., hov thay are populated fros the translational enercy of the shock vave and if thay are in equilibriun. In the case of the aboye systea, conpression elther uning shock-wave techniques or statically using a dianond-anvil cell, vill Induce : relative shift in the $v_{1}, v_{6}$ and $v_{2}$ lavels that should chanse the resonant coupling of the $C B$ fundanental levels and the $v_{2}$ overtone. The relaxation time should change accordingly.

Figire 17 schematic shous an experiment to measure the change in the CH stretch rode energy relaxation time at high pressure and tewperature. Sub-picosecond pulses from a colliding-pulse-wode-locked ring dye laser ${ }^{87}$ vill be anplified using an excimer laser driven four stage amplifier and then used to generate picosecond infrared pulses which vill vibrationally excite, by infrared absorption, the $\mathrm{CH}$ stretch levels of the substituted methanes. Part of the origlnal amplified pulse vill be optically delayed and used to probe the population density of the exclted stato by spontaneous anti-stokes kaman scatcering. Experiment repetition rate is $100 \mathrm{Bz}$.

The Raman scattering signdls vill be detected by either a high quantio efficlency photo multiplier tube equipped vith sultable flitars or in a spectrograph using an optical multichannel anelyzer. Compression of the sample to several GPa vill be accomplished using a dlamond anvil or other high pressure cell.

Experiment detalls and results will be described in a future publication. It is hoped that this experiment can be used to study the intra- or intar-molecular relaxation phenomenology at densties sidilar to those existing during shock compression. At pressures of several GPa, the molecules may not exist individually but as some other type of structure vith radically shifted energy levels. Interpretation vould require a theoretical approach which differs significantiy from the frequently used bimolecular collision model. 
v. SUMMARY

Pundanental understanding of the detatled afcroscople phenomenolocy of shock-induced cheaicai reaction and detonation vaves is being sought by using pulsed coherent optical scattering experinents to detezune the nolecular structure, constituents add energy transfer mechanisas in both shock-coupressed and static, high pressure/high tesperature fluids. To date measurements of the ring stretching mode of benzene and the CN stretching mode of nitrowethane up to shock-induced pressures just below those for which reaction is suspected to occur have show both a shift in the vibrational frequencies and a definite change in the spectral profile. These results have confirmed that these molecules still exist on the wicrosecond tine scale behind the shock front, but that sone form of energy transfer is occirring from the hydrodynamic mode to the nolecular internal degrees of t:eedom. Future experiments, both static high pressure picosecond vibrational relaxation and dynamlc coherent Raman scattering at shock-compression pressures in the region where reaction is expected, should yleld significant insight tovard understanding the very complex and rapid processes that prevail in the shock envitonment.

\section{ACKNOVLEDGEMENTS}

The authors ish to thank C. W. Caldvell, R. L. Eavenson, and R. S. Medina for their assistance in performing the shock-coupression experiments and V. A. Gusule, C. N. Gomez, and R. W. Livingston for machining and fabrication of the target assemblies. Special thanks is given to J. N. Fritz for use of the MACRAME computer code used to design target assomblies.

\section{REFERENCES}

1. C. A. Porest, "Burning and Detonation," LA-7245 (Los Alamos National Laboratory Report, Los Alamos, New Mextco 1978). 
2. c. L. Mader, Nueerical Modeling of Detonation (University of Cal1fornia Press, Berkeley, Callfornia 1979).

3. E. L. Lae and C. M. Tarver, Phys. Flu1ds 23, 2362 (1980).

4. J. Vackerle, R. L. Rabie, H. J. Ginsberg and A. B. Andarson in Proceedings of the Symposium on Bigh Dynanic Pressures (Conmissariat á L'Energie Atonique, Paris, France 1978) p. 127.

5. M. Covperthvaite in Proceedings of the Symposiue on Bigh Dynanic Pressures (Commissariat á l'Energie Atomique, Paris, France 1978) p. 201.

6. J. W. Nunizato in Shock Vaves in Condensed Matter-1983, J. R. Asay, R. A. Graham, and G. K. Straub, eds. (Elsevier Sclence Publishers B. V., 1984) p. 293.

7. J. H. Nunizato and E. K. Valsh, Arch. Ratlonal Mech. ana?. 73, 285 (1980).

8. J. N. Johnson, P. K. Tang and C. A. Fozest, J. Appl. Phys. 57, 4323 (1985).

- P. K. Tang, J. N. Johnson and C. A. Forest in Proc. 8th Symp. Detonation (Albuquerque, Nev Mexico 1985), p. 375.

10. C. Mader and J. Kerschner in Proc. 8th Symp. Detonation (Albuquerque, New Stextco 1985) p. 366.

11. F. Boisard, C. Tombini and A. Menil in Proc. 7th iymp. Detonation, (Annapolis, Maryland 1981) p. 531.

12. A. De lpuech and A. Menil, in Shock Uaves in Condersed Katter - 1983, J. R. Asay, R. A. Graham, and G. K. Slraub, ads. (Blsevier Sclence Publishers B. V., 1984) p. 309. 
13. S. Dufort and A. Delpuech in Proc. 8th Syap. Detonation, Albuguerque, Nev Mexico 1985) p. 221.

14. N. C. Bolnes, A. C. Mitchell, U. J. Nellls, U. B. Grahan and G. E. Valrafen, in Shock Vaves in Condensed Matter - 1983, J. R. Asay, R. A. Grahan and G. R. Straub, eds. (Blsevilas Science Publisher B.V., 1984) F. 307.

15. H. M. Trott and A. M. Renlund in Proc. 8th Symp. Detonation, (Albuquerque, Nev Mexjco 1985) p. 416.

16. D. S. Moore, S. C. Schmidt, D. Schiferl, and J. Y. Shaner, in Los Alamos Conference on Optics '83, R. S. McDovell ard S. C. Sroilar, eds. (Proceedings SPIE Volumi 380, 1983) p. 208.

17. S. C. Schmidt, D. S. Moore, D. Schiferl, and J. W. Shaner, Phys. Rev. Lett. 50, 661 (1983).

18. D. S. Moore, S. C. Schmidt, and I. W. Sharer, Phys. Rev. Lett. so, 1819, (1983).

19. S. C. Schmidt, D. S. Moore, and J. H. Shaner, in Shock Vaves in Cundensed Mattor-1983, J. R. Asay, R. A. Graham, and G. K. Straub, eds. (Elsevier Science Publishers B. V., 1984) p. 293.

20. D. S. Moore, S. C. Schmidt, D. Schlferl, and J. W. Snaner, in Blgh Pressure In Science and Technolory, Part II, C. Boman, R. K. MacCrone, and E. Whalley, eds. (North Bolland Publishing, Nev York, 1984) P. 87.

21. S. C. Schmidt, D. S. Moore, J. H. Shaner, D. L. Shampine, and W. T. Holt in Xth AJRAPT Bigh Pres.ure Conterence, Unlversity of Ansterdan, Amsterdam, The Netherlands, 8-11 July 1985. 
22. D. S. Hoore, S. C. Schaidt, J. Y. Shancr, D. L. Shanpine, and v. T. Bolt in Pourth APS Topical Conferance on Shoek Daver in Coadensed Matrer, Sprtane, Uashington, USA, 22-25 July, 1985.

23. A. Delpuech, J. Cherville, and C. Michaud in Proc. 7th Syep. Detountion, (Annapol1s, Maryland 1981) p. 36.

24. J. Alster, M. Slage, H. J. S. Devar, J. P. Ritchie, and C. Wolls in Past-Reactions in Enerretic Systras, C. Capellas and R. F. Valker, eds. (D. Reidel Publishing Co., 1981) p. 695.

25. R. Engelke, v. L. Barl and C. M. Rohlfing, J. of Chen. Phys., to be publisined.

26. S. B. Korwer, Sov. Phys.-Uspekh: 11, 229 (1968).

27. A. N. Drewin and V. Yu. Klinienixo, "On the Role of the Shock Wave Front in Organle Substances Decorfosition," Gas Cynanics of Explosions and Reactive Systems, Minsk, USSR 1981.

28. A. N. Dremin, V. Yu. K.limenko, K. M. Michaijuk and V. S. Trofimov in Proc. 7th Syap. Detonation (Annapolis, Mary) and 1981) p. 789.

29. H. C. Davis in Proc. 7th Symp. Detonation (Annapoiis, Maryland 1981) p. 531 .

30. M. Maler, U. Kaiser and J. A. Glordmaine, Phys. Rev. 177, 580 (1969).

31. D. V. J. Linde, M. Maler and V. Kalser, Phys. Rev. 178, 178 (1969).

32. H. B. Rice, R. G. McQueen and J. M. Valsh, Solld State Physics 6 (Academic Press, New York 1958) p. 1.

33. R. D. D1ck, J. Chen. Phys. 57, 6021 (1970). 
34. J. N. Fritz, in preparation for publication.

35. U. D. Ellenson and H. Nicol, J. Chen. Phys. 61, 1380 (1974), this mode is called $v_{2}$ in G. Berzberg, Infrared and Ranan Spectra (Van Nostrand Reinhold, Nev York 1968).

36. R. N. Reeler, G. B. Bloon and A. C. Mitcheli, Phys. Rev. Lett. 17, 852 (1966).

37. A. N. Dremin and L. V. Barbare in Shock Vaves in Condensed Matter-1981, Am. Inst. Phys. Proc. 78. H. S. Nellis, L. Seaman, and R. A. Graham eds. (New York 1983), p. 270.

38. L. V. Barbare, A. N. Dremin, S. V. Pershin and V. V. Yakovlev, Fiz. Gor. 1 Var S, No. 4, 528 (1969).

39. R. LeSar, S. A. Ekberg, L. h. Jones, R. L. Mllis, L. A. Schualbe, and D. Schiferl, Solid State Comm. 32, 131 (1979).

40. S. Block, C. E. Veir, and G. J. Plermartni, Sclence 169, 586 (1970).

41. J. Akella and G. C. Kennedy, J. Chew. Phys. 55, 793 (1971).

42. P. D. Maker a.d R. U. Terhune, Phys. Rev. 137, 1801 (1965).

43. U. M. Tolles, J. Y. Nibler, J. R. McDonald and A. B. Barvey, Appl. Spectrosc. 31, 253 (1977).

44. J. Y. Nibler and G. V. Krighten, in Raman Spectroscopy of Gases and Liquids, A. Veber, ee. (Springer-Verlag, Berlin Beidelberg, 1979) p. 253.

45. A. C. Eckbreth and P. Y. Schrelber, in Chemlcal Applications of NonInear Raman Spestroscopy, A. B. Barvey, ed. (Acadosic, Now York, 1981), P. 27. 
46. Y. B. Roh, P. Y. Schretber, and J. P. B. Taran, Appl. Phya. Lett. 29, 176 (1976).

47. J. J. Valentini, D. S. Moore, and D. S. Bonse, Chen. Phys. Lett. 83, 217 (1981).

48. H. J. Nellis, F. G. Ree, R. J. Trainor, A. C. Mitchell and M. B. Boslough, J. Chew. Phys. 80, 2784 (1984).

49. O. B. Yakusheva, V. V. Yakushev and A. N. Dremin, Bigh Teap.-Bigh Pres. 3, 261 (1971).

50. B. U. Dodson and R. A. Graham in Shock Yaves in Condensed Matter-1981, Aol. Inst. Phys. Proc. 78, U. S. Nellis, L. Seanan, and R. A. Graham, eds. (Ney York 1981).

51. P. C. Lysne and D. R. Hardesty, J. Chen. Phys. 59, 6512 (1973).

52. F. E. Walker and R. J. Vasley, Comb. Flame 15, 233 (1970).

53. J. W. Brasch, J. Phys. Chem., 84, 2085 (1980).

54. D. R. Bardesty, Comb. Flame 27, 229 (1976).

55. A. A. Vorob'ev and V. S. Trotimov, F12. Gor. 1 V2r 18. Nov. 6, 14 (1982).

56. A. N. Dremin, V. Yu. Klimenko and I. Yu. Kosireva in Proc. 3th Symp. Detoration (Albuquerque, Nev Mextco 1985) p. 407.

57. D. Schiferl, private comounication.

58. D. T. Croner, R. R. Ryan and D. Schiferl, J. Phys. Chem. 89, 2315 (1985). 
59. D. Belaan, R. U. Bellworth, M. D. Levenson and G. Martin, Phys. Rav. Latt. 36, 189 (1976).

60. H. G. Vontolle and R. A. Mellillians in Leser Probes for Conbustion Chealstry (Anerican Chenical Society Sympostun Series 136),

D. R. Crosley, ed. (Awertican Chentcal Society, Deshington, D.C. 1993), P. 319.

61. G. L. Eesley, Coherent Raaan Spectroscopy (Perganon Press, Oxford 1981).

62. H. D. Levenson in: Chenical Applications of Nonlinear Raman Spectroscopy, A. B. Barvey, ed. (Acaderic Press, Noy virk 1981) pp. 214-222.

63. V. P. Calavay and G. E. Eving, Chem. Phys. Lett. 30, 485 (1975).

64. V. F. Calavay and G. E. Eving, J. Chem. Phys. 63, 2842 (1975).

65. C. Manzanares and f. E. Eving, J. Chen. Phys. 69, 1418 (1978).

66. C. Manzanares and G. B. Eving, J. Chea. Phys. 69, 2803 (1978).

67. D. Y. Chandler and G. E. Eving, J. Chem. Phys. 73, 4904 (1980).

68. D. V. Chandler and G. E. Eving, J. Phys. Chem. 85, 1994 (1981).

69. W. Kaiser and A. Laubereau in Nonlinear Spectroscopy (Proc. International School of Physics "Enrico Feral," Course LIIV),

N. Bloemberger, ed. (North-holland Publishing Co., Ansterdam 1977), p. 404 .

70. A. Laubereau and W. Ralser, Rev. Mod. Phys. S0, 607 (1978).

71. D. Santos and Th. Dorfauller, Mol. Phys. 41, 637 (1980). 
72. Th. Dorfauller and D. Sanios, Mol. Phys. 43, 23 (1981).

73. R. Takag1, P.-K. Choi and R. Neg1sh1, J. Acoust. Soc. Am. 62, 354 (1977).

74. K. Takagi and R. Negish1, J. Chem. Phys. 72, 1809 (1980).

75. K. Takagi, P.-R. Chot and K. Negishi, J. Chem. Phys. 74, 1424 (1981).

76. P.-K. Choi, K. Takagi and K. Negishi, J. Chem. Phys. 74, 1438 (i981).

77. J. T. Yardley, Introduction to Molecular Energy Transfer, (Academic Press, New York 1980).

79. C. Capellos and R. F. Valker, Fast Reactions In Energetic Systems, (D. Reidel Publishing Co., Dordrecht, Holland 1980).

79. P. M. Rentzepls, Scierce 218, 1183 (1982).

80. J. Chesnoy and G. M. Gale, "Vibrationel Energy Relaxation in Liquids," in preparation.

81. M. Chatelet, G. Wivenlocher and B. Oksengorn in Bdgh Pressure Science and Teihnology, Vol. 2, B. Vodar and Ph. Marteau, eds. (Pergamon Press, Oxford 1979), p. 628.

82. M. Chatelet, B. Oksengorn, G. Widenlocher and Ph. Martezu, J. Chem. Phys. 75, 2374 (1981),

83. M. Chatelet, J. Kleffer ind B. Oksengorn, to be published Chem. Phys.

B4. A. Laubereau, S. F. Fisher, K. Spanner, and W. Kalser, Cheia. Phys. 31, 335 (1978). 
85. B. Graener and A. Laubereau, Appl. Phys. B29, 213 (1982).

86. A. Fandt, S. P. Pischer, and V. Raiser, Chen. Phys. 57, 55 (1981).

87. R. L. Fork, B. I. Greene, and C. V. Shank, Appl. Phys. Lett. 38, 671 (1981). 


\section{PIGURE CAPTIONS}

Pig. 1. Condeneed-phase eolecular onergy transfer.

Fig. 2. Refractive effects of shock vave on optical baan.

Pig. 3. Detonation vave aicrostructure for nitronathane and a nitrome thane/ace tone mixture. 28

F18. 4. Coherent Raman scattering techniques.

Pig. 5. Schematic representation of backuard stimulated Raman-scattaring experiment. SHG, second harmonic generator; Barm. Sop., haraonIc separator. Sample, liquid benzene.

Fig. 6. Scattered light spectrogram for shock-compressed benzene.

Fig. 7. Benzene ring-stretching mode vibrational frequency shifts (with respect to $992 \mathrm{~cm}^{-1}$ ) vs pressure. The solid circles represent date obtalned up to pressures of $1.2 \mathrm{GPa}$ using the oingle etage gas gun and the open circles represent data obtained using the two stage light gas gun. The straight line la e tlt of ine shock-compressed data at prossures less than $1.2 \mathrm{GPa}$. The phase of the lenzene during the diamond-anvil cell compression has been decermined from phonon specirum measurements. At $24 \mathrm{C}$ benzene I vas observed as a metastable phase above 1.2 GPa and benzene II vas observed as a uetastable phase belov this pressure. Both spectrometers vere callbrated vith liquid benzone at room temperature.

F1g. B. Schematic representation of the reflected broudband coherent ent1-Stokes Raman scattering experiment. SEG - second harmonte generatori Barm. Sep. - hermonlc separatorl OMA - optlcal wultlchannal analyzer; Sample - benzene and nltromethane. 
118. 9. RBBCARS spectra of anbient and shock-coapressed benzene. The abbient peak postition of the benzene 1s $992 \mathrm{~cm}^{-1}$. Shock pressures are indicated. Wavelength calibration vas done reletive to the $253.652 \mathrm{~nm}$ Bg line in second order.

P18. 10. Spactral fit of 7.4 GPa ring strutching aode of bensene. Vavelength calibration is with respect to the $253.652 \mathrm{nn}$ Hg line in second order and the spectral slit vidth is $4.2 \mathrm{~cm}^{-1}$.

Pig. 11. RBBCARS spactra of ambient and shock-compressed nitromethane. The ambient pcak positicn is $920 \mathrm{~cm}^{-1}$. Shock pressures are indicated. Wavelength callbration vas done with respect to the $253.652 \mathrm{~nm}$ Bg line in second order.

Fig. 12. Spectral fit of $5.5 \mathrm{GPa}$ CN stretching mode of nitromethane. Vavelength calibration is with respect to the $253.652 \mathrm{~nm} 8 \mathrm{~g}$ ine in second order and the spectral slit width is $4.2 \mathrm{~cm}^{-1}$.

Fig. 13. Nitromethane $C N$ stretching mode vibrational frequency shifts (with respect to $920 \mathrm{~cm}^{-1}$ ) vs pressure.

P1g. 14. Schamatic representation of the Ranan-induced Rerr effect spectroscopy experiment. SBG - second harmonic generator; Harm. Sep. - harmonic separator; OMA - optical multichenna? enalyzer; Semple - benzene.

F1g. 15. Raman-1nduced Kerr effect spectra (RIKES) af an ambient and tro shock-compressed liquid benzene samples. The shock pressure was $1.17 \mathrm{GPa}$ and the $557.03 \mathrm{~nm}$ and $556.22 \mathrm{na} \mathrm{Kr}$ callibretion lines are shown. All spectra are obtained at the same pover lovels. 
18. 16. Vibrational energy levels, sone overtones and conblantions and Infrared spectre: $\mathrm{Ca}_{2} \mathrm{Cl}_{2}, \mathrm{Cl}_{2} \mathrm{Dr}_{2}$ and $\mathrm{Cl}_{2} \mathrm{I}_{2}$. The vibrational relaxation tiese, $\tau_{1}$, show with the Infrared absorption spectra are the masured enercy decay tians of the C. strotching aodes.

918. 17. Pressure dependent vibrational relaxetion tiee experieent. 


\section{Electronic} Excitation (Equilibriual Nonequilibriun)
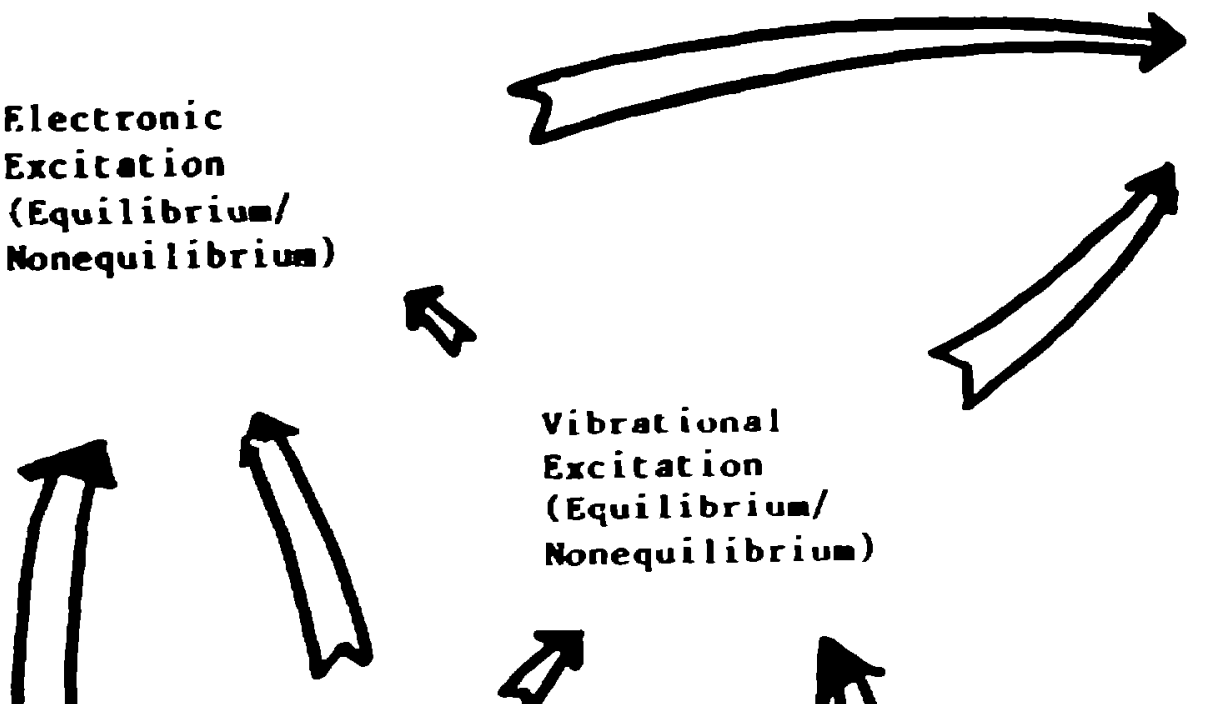

\section{Excitation}

(Equilibrium/

Nonequilibriun)

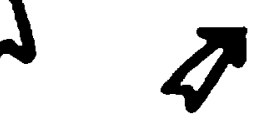

ALTERED MATERIAL

Altered Structure

Molecular Rearrangement

Phase Change

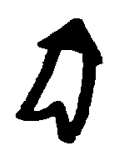

SHOCKHAVE

MATERIAL

Density

Temperat ure

Mechanical Deformation

Hydrodynamic Effects

Radiation
INITIAL MECHANISM

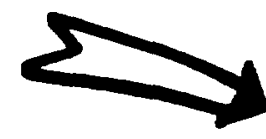

Bond

ENSUING

Breakage

Vibrationally

Fixcited-St at e

Reaction

Dissociation

Phot ochemical

Reaction

Molecular

Abstraction

Bond

Fornation

\section{STEPS}

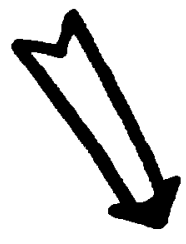

PRODUCTS

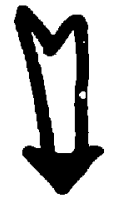

EXPANSION 


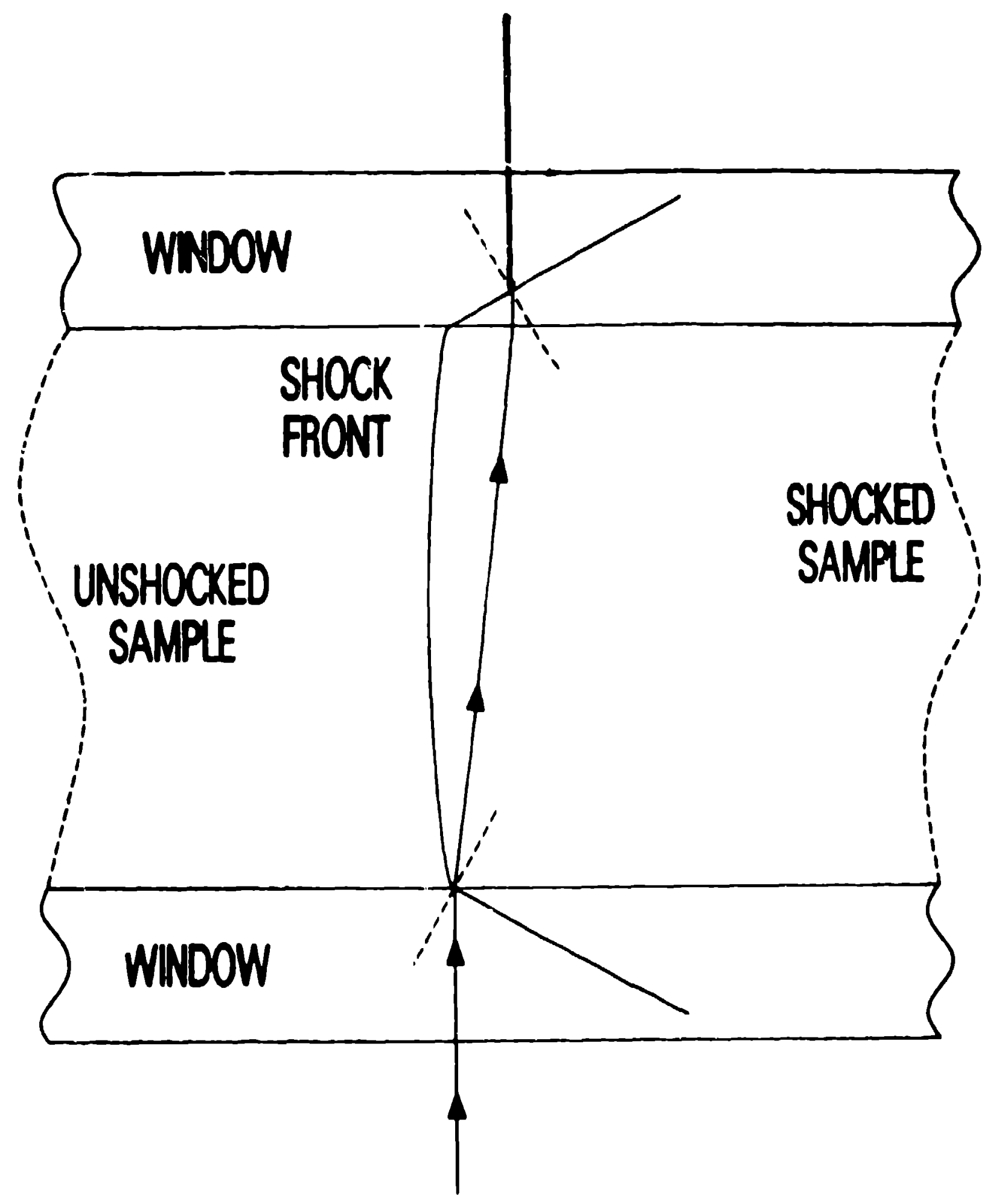

OPTCAL BEAM 


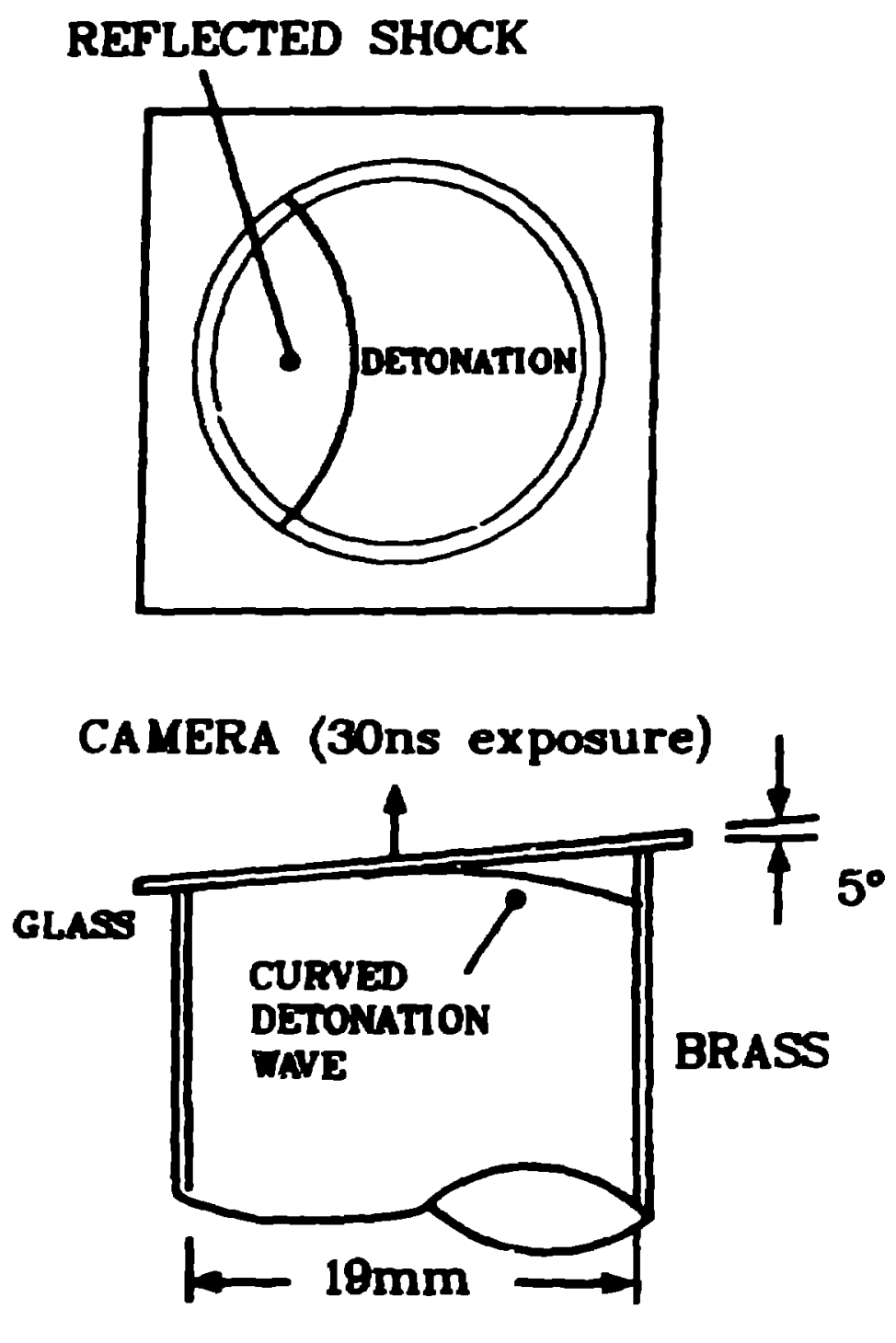

FROM DAVIS

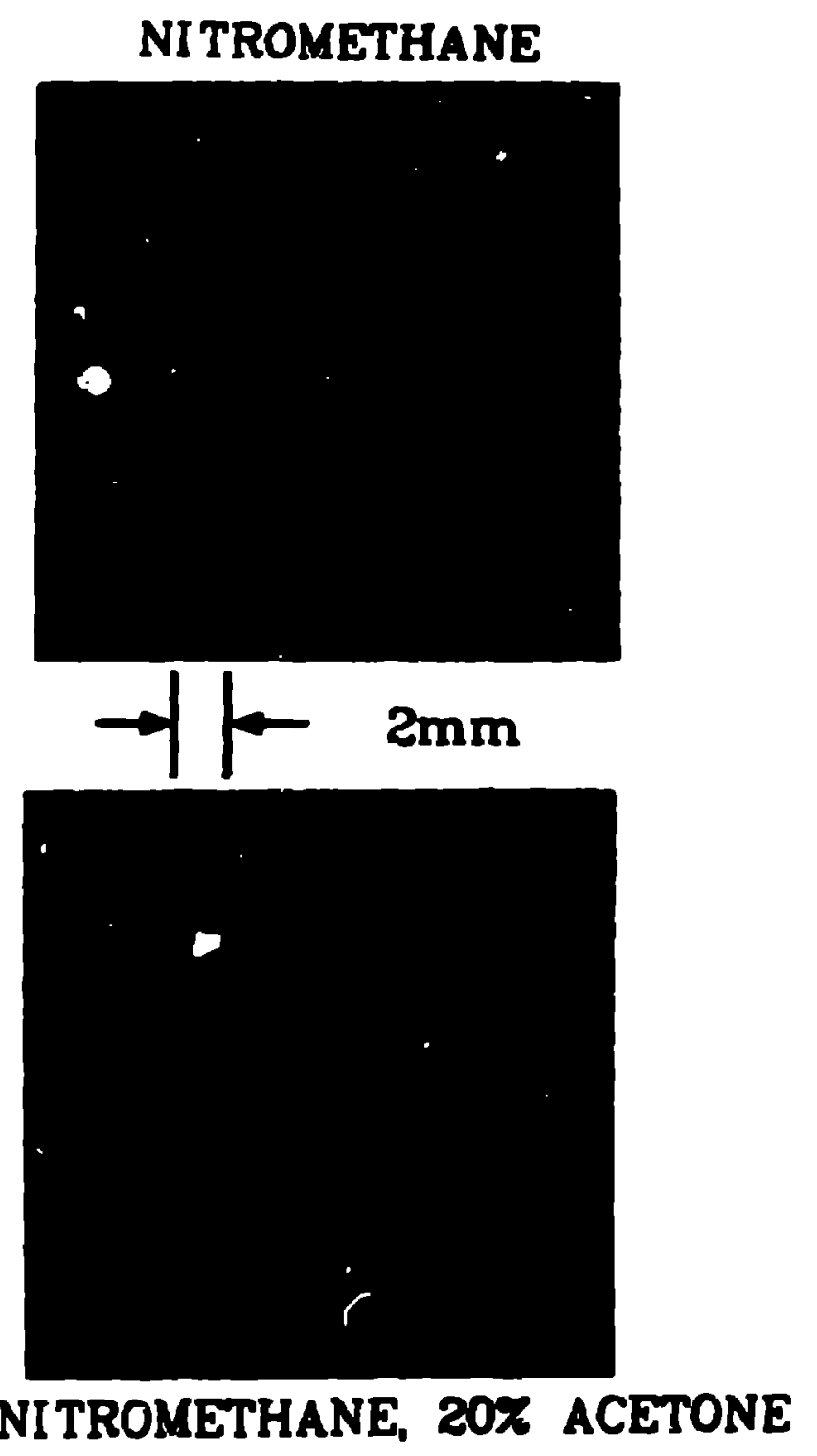


HIGHER ORDER RAMAN EXCITATION SPECTROSCOPY

THREE INPUT FREOUENCIES
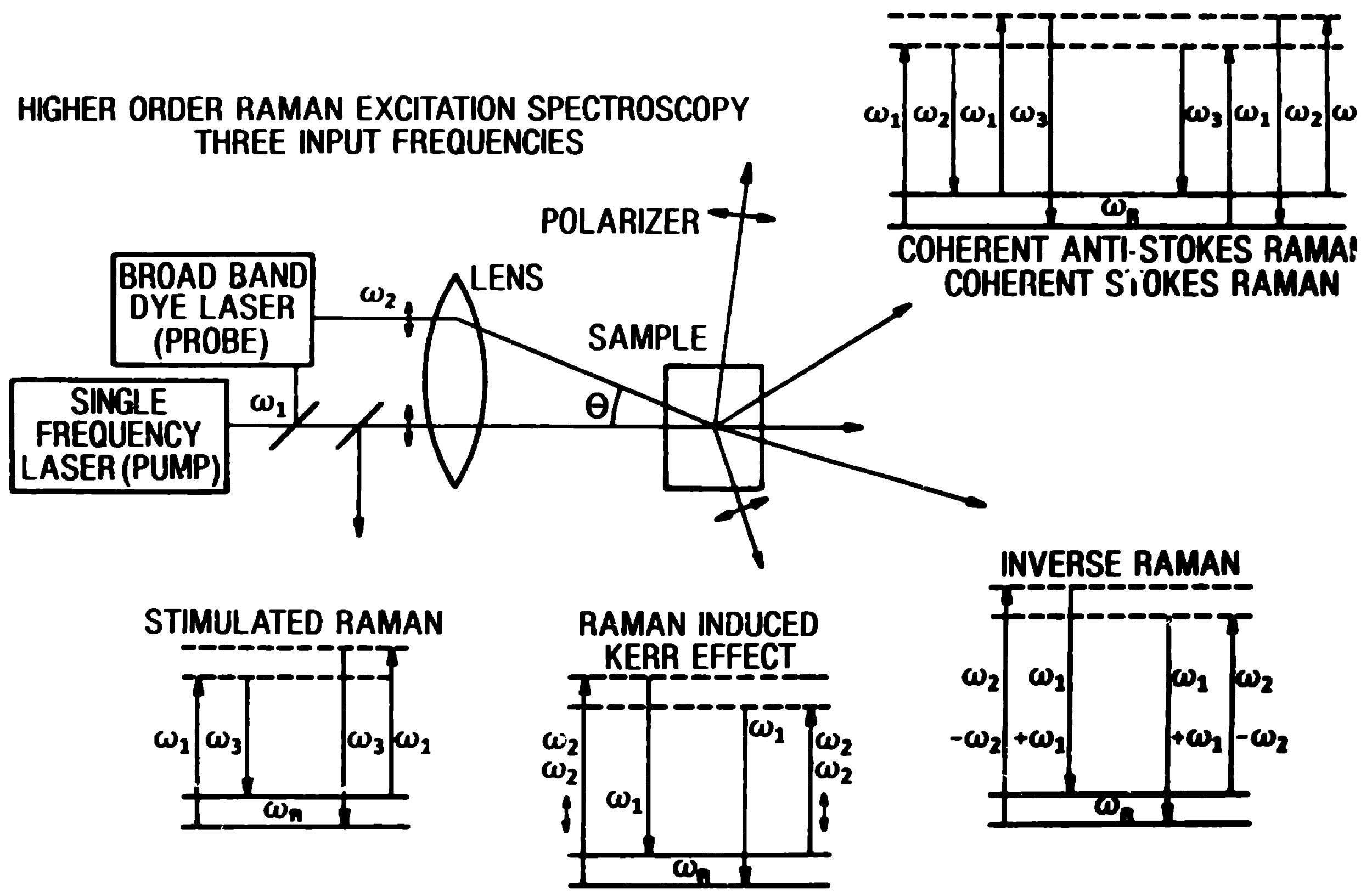


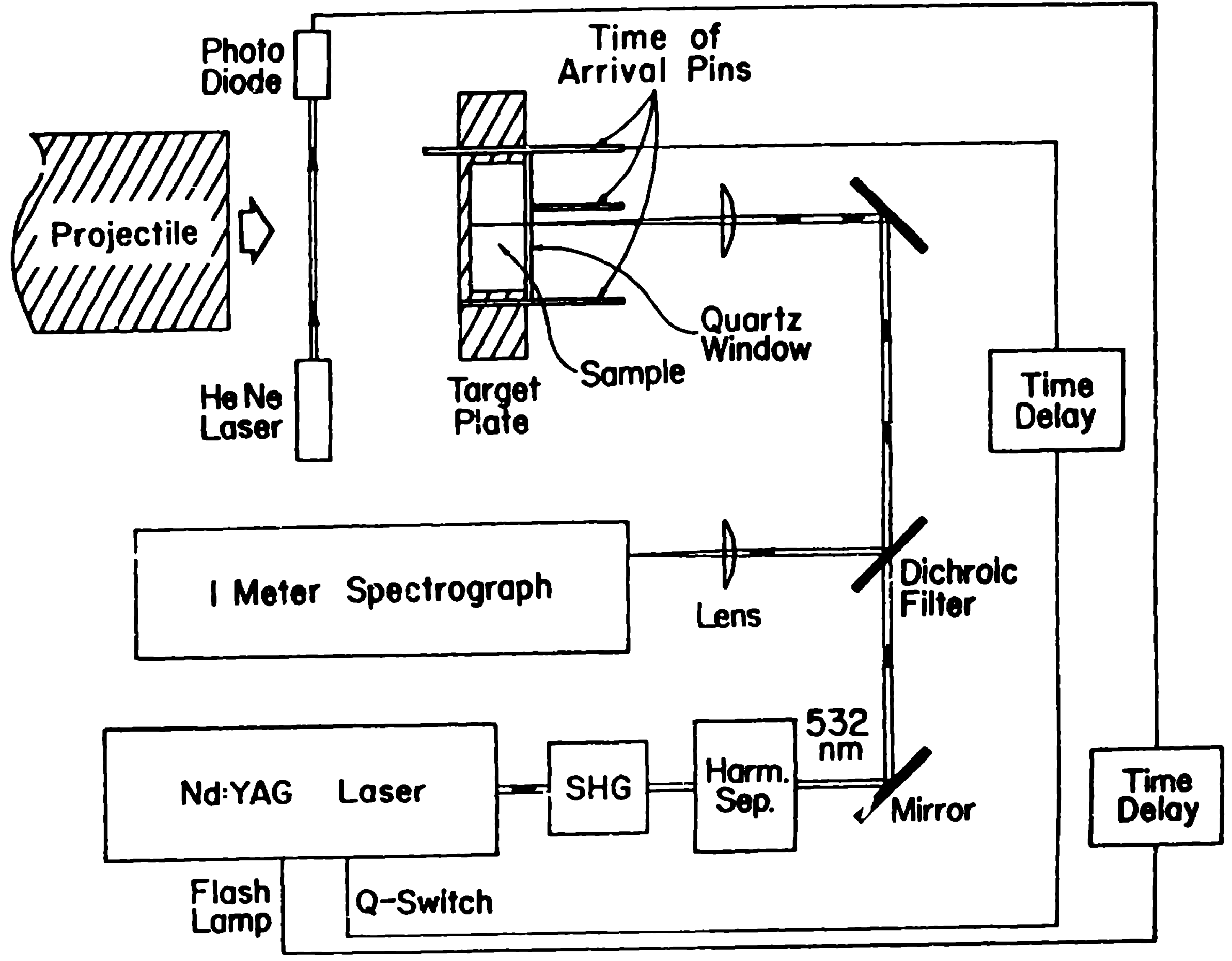


$\rightarrow 1-100 \mathrm{~cm}^{-1}$

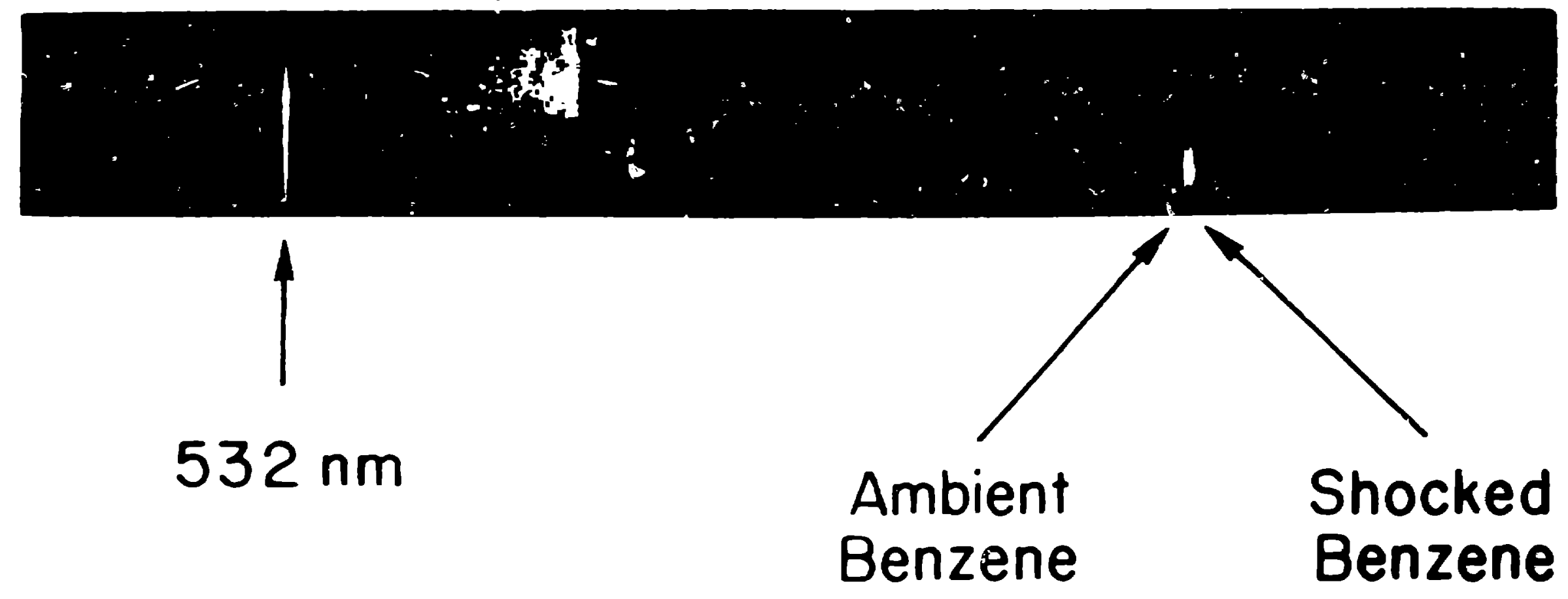




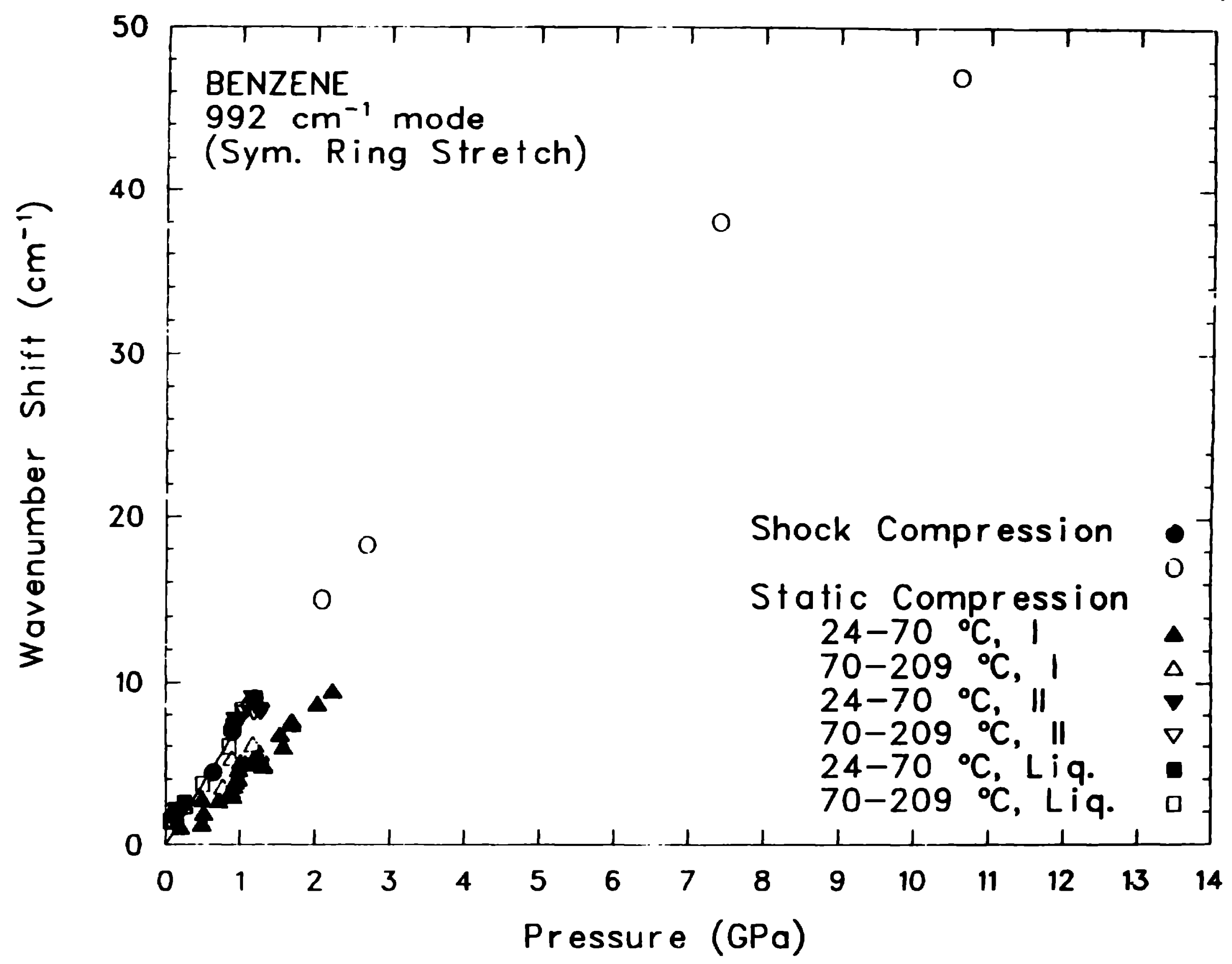




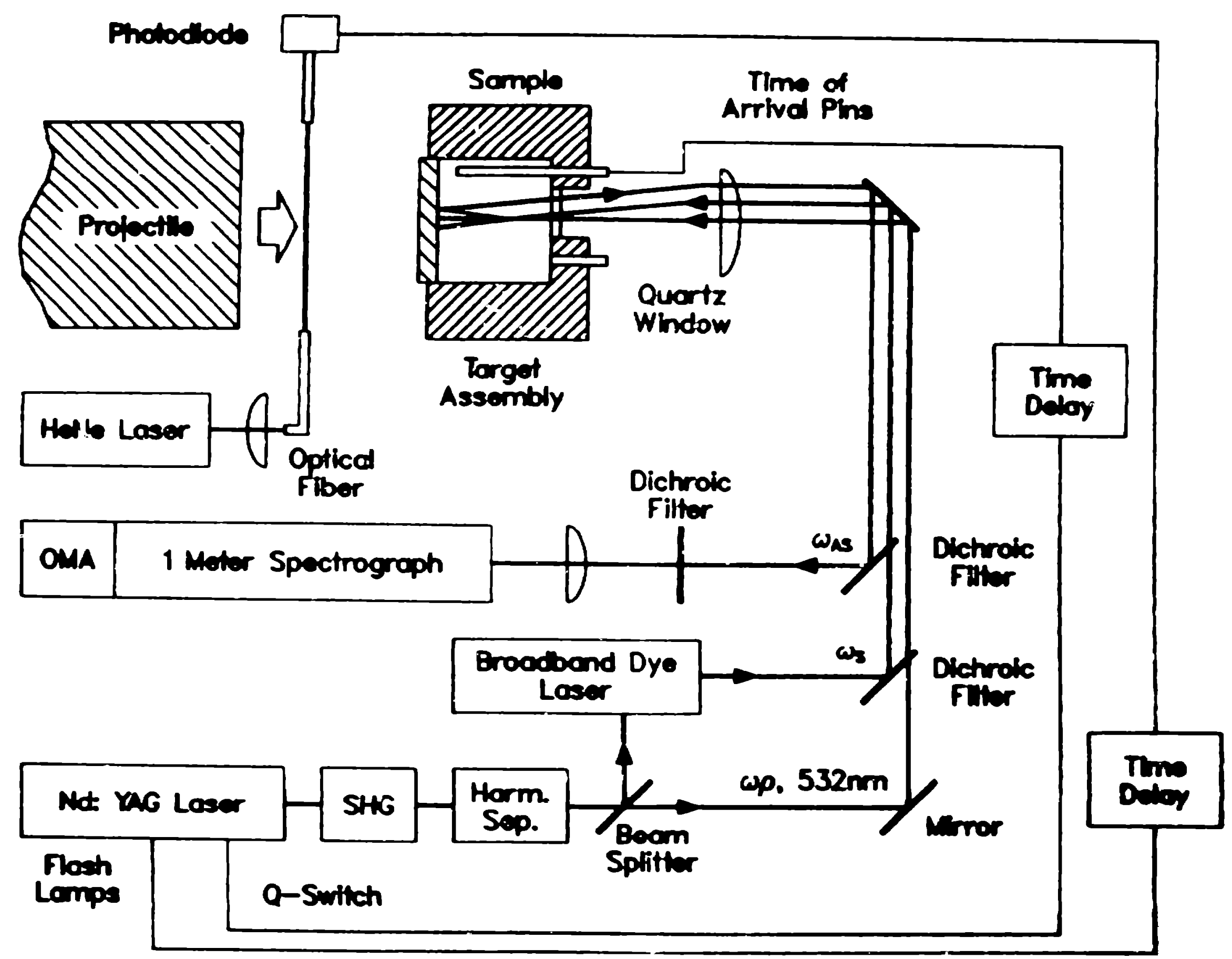




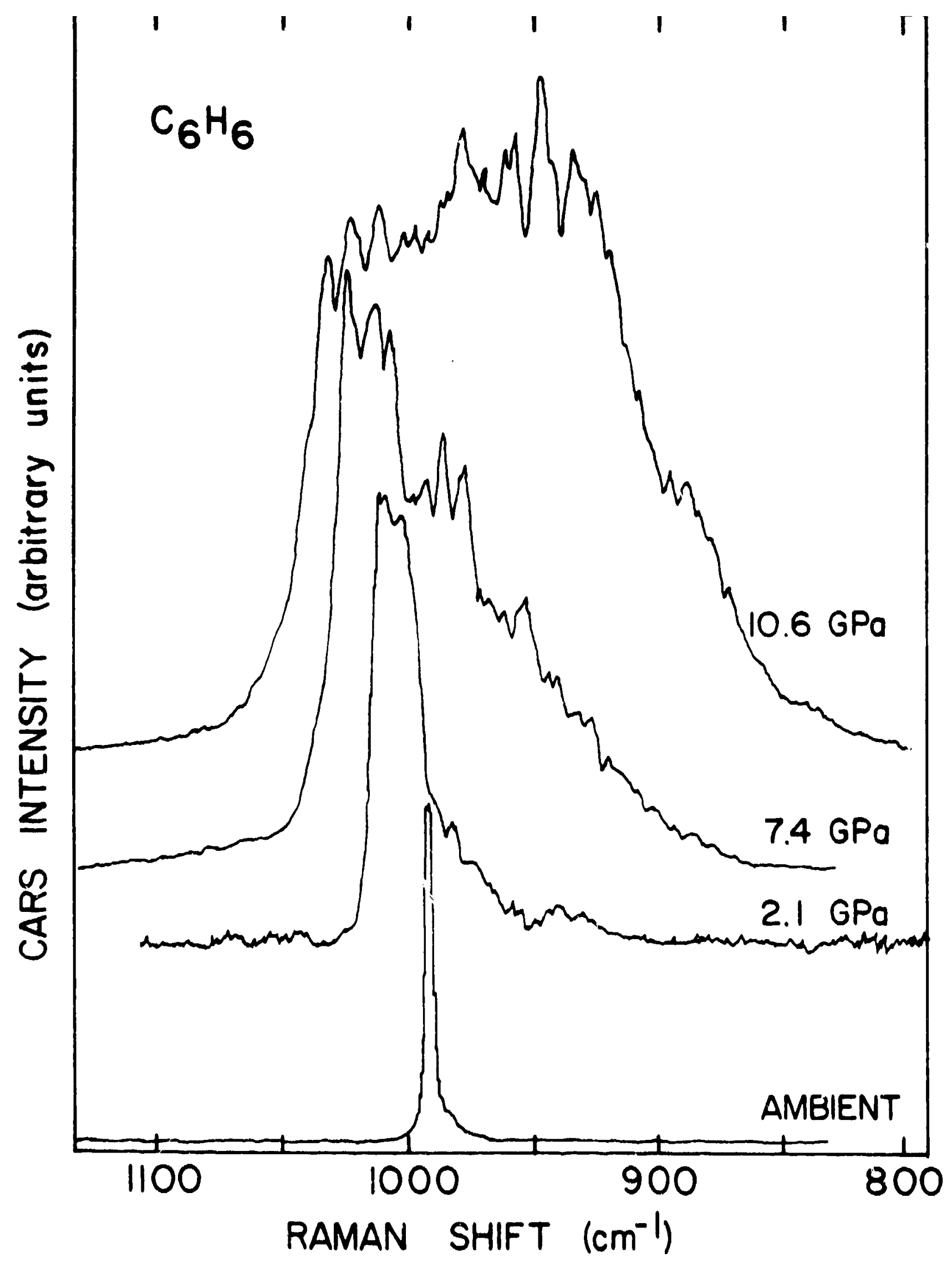

CHM-VG-8196 


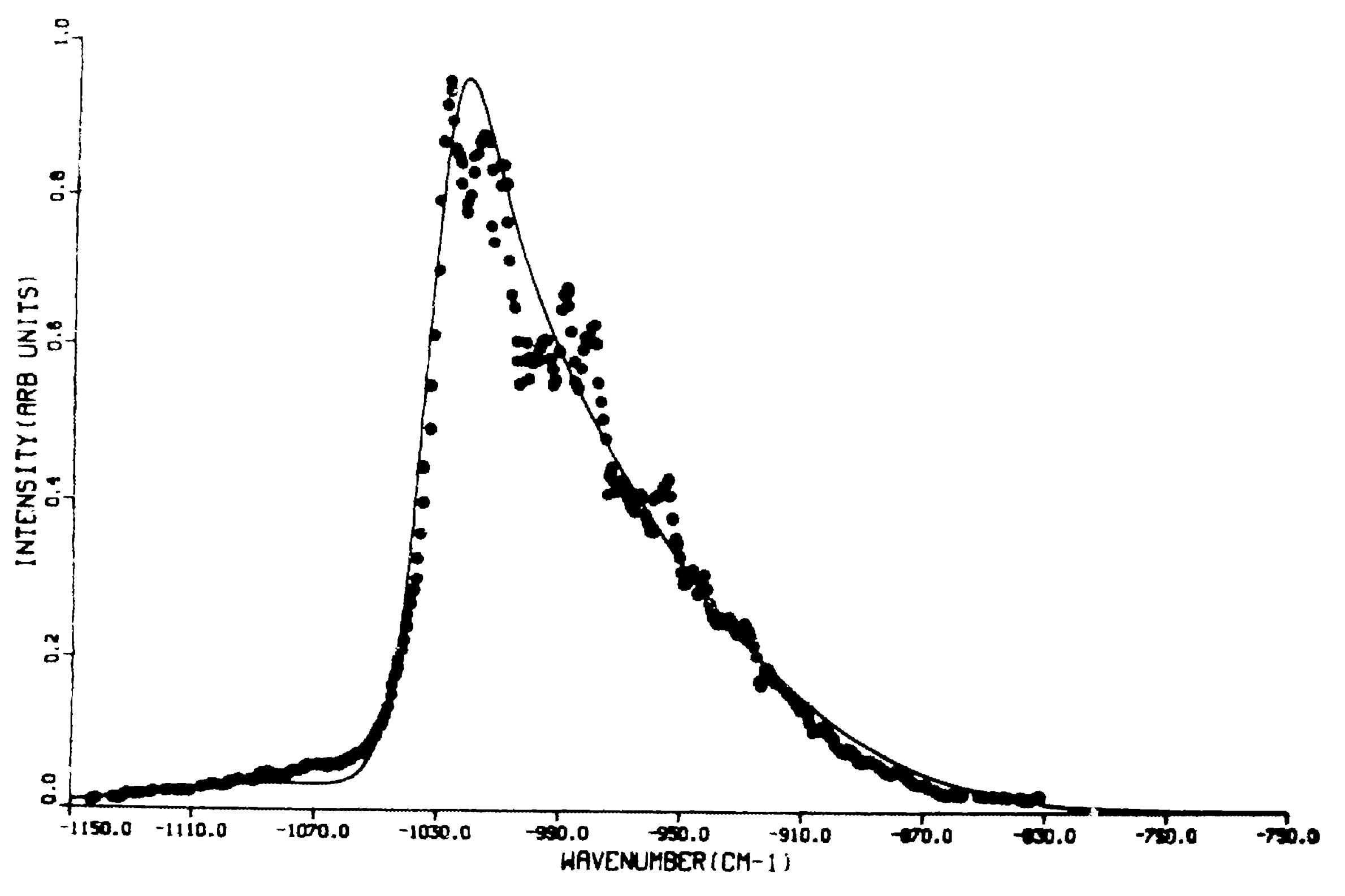




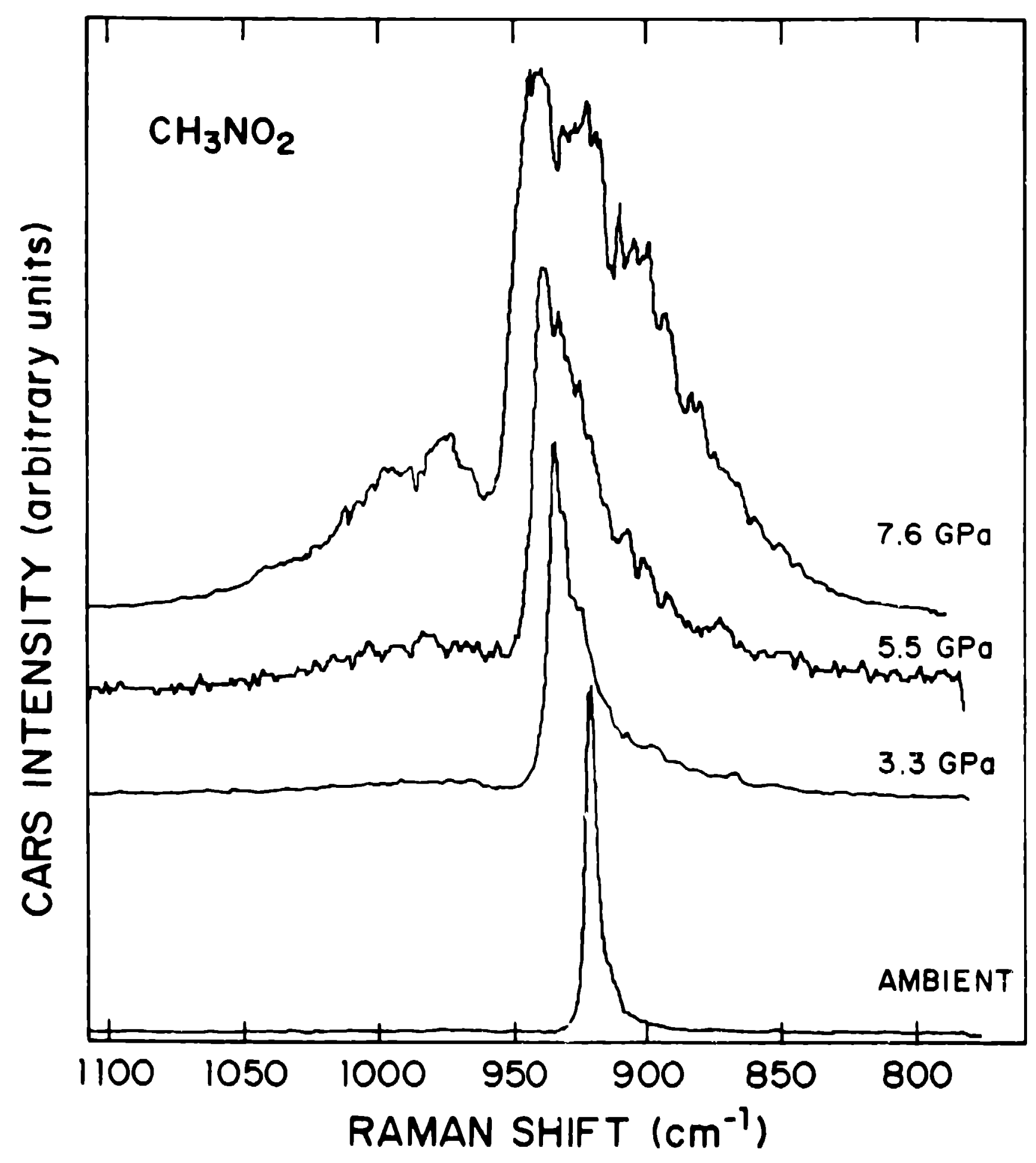




$$
L
$$




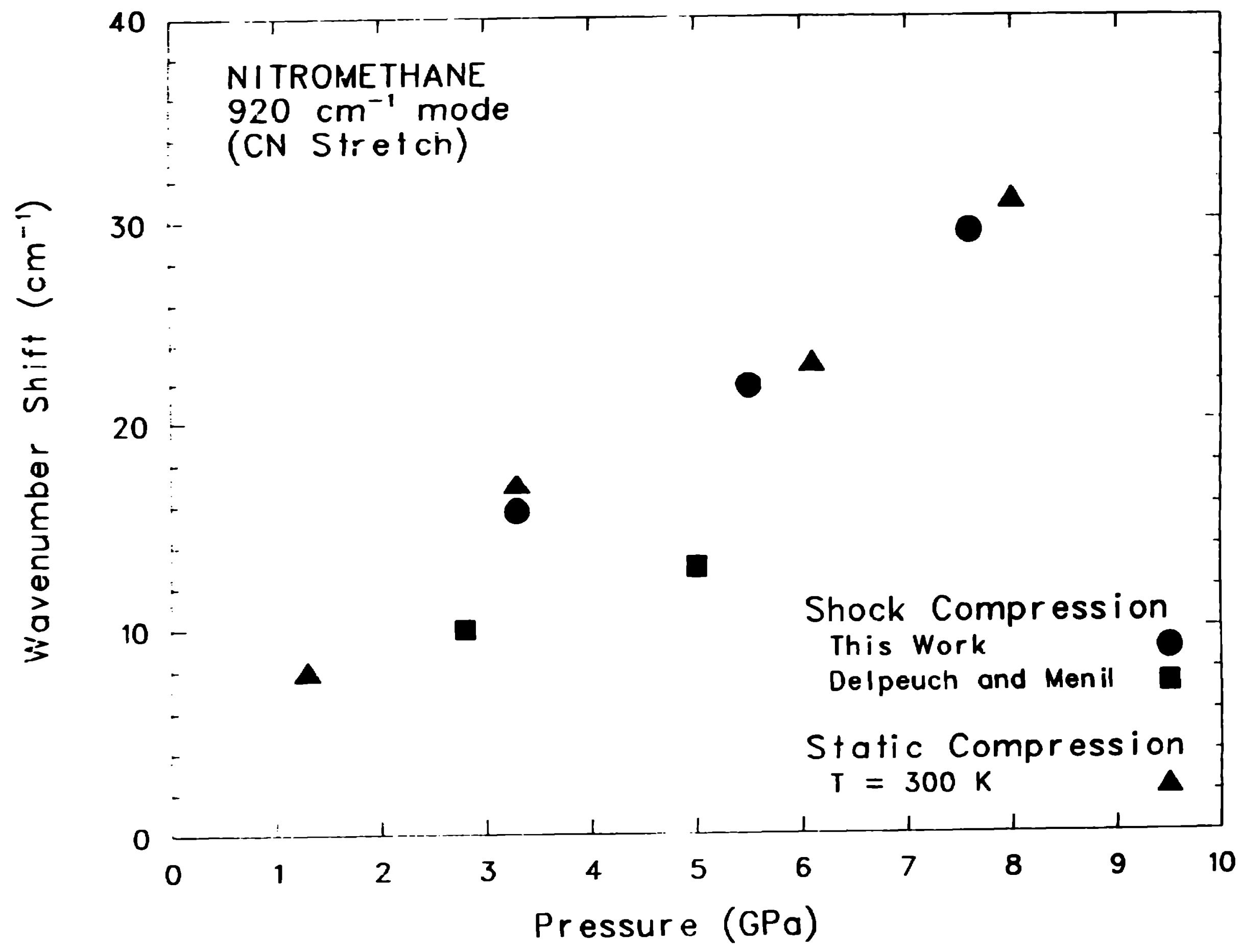




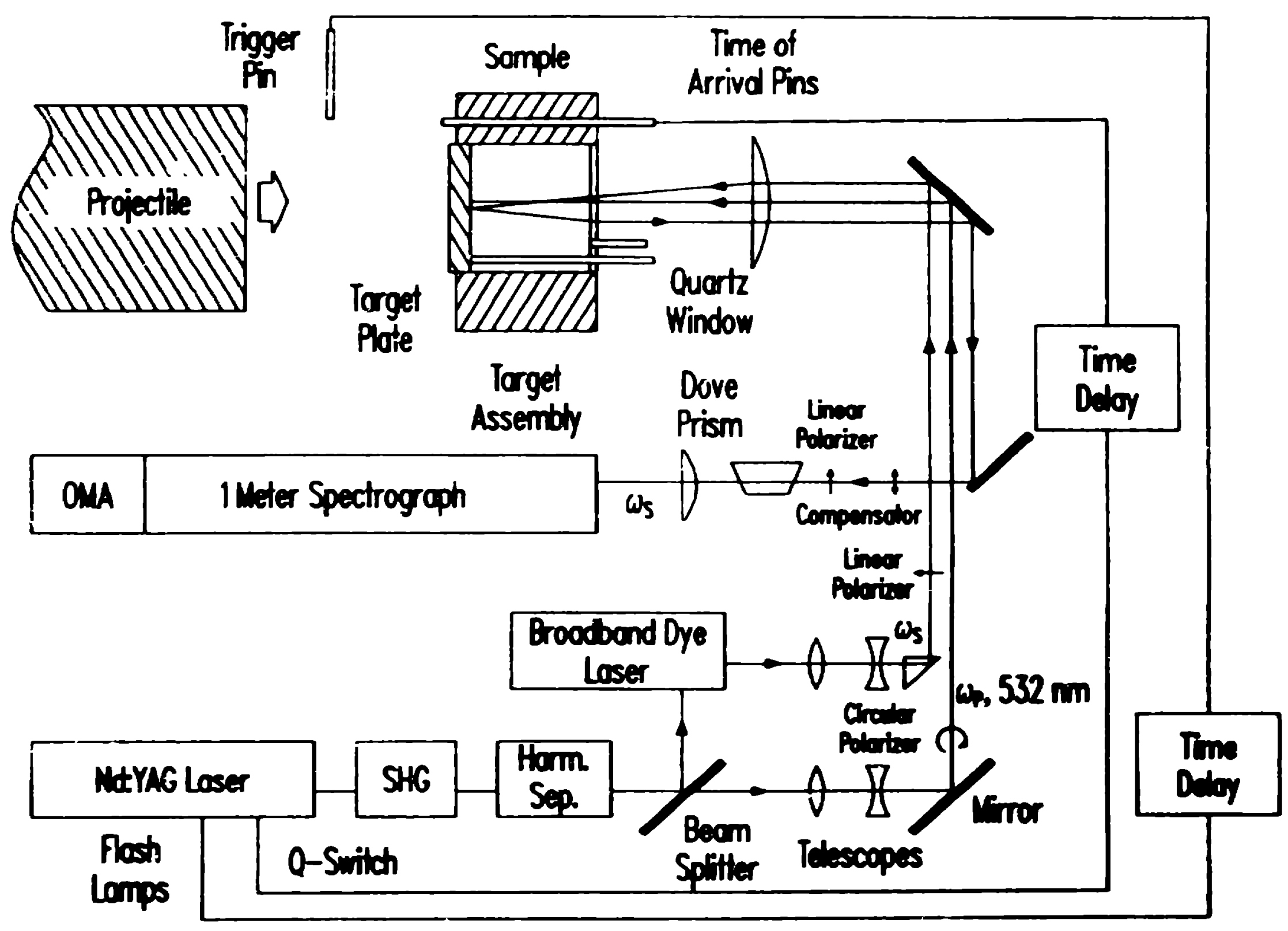




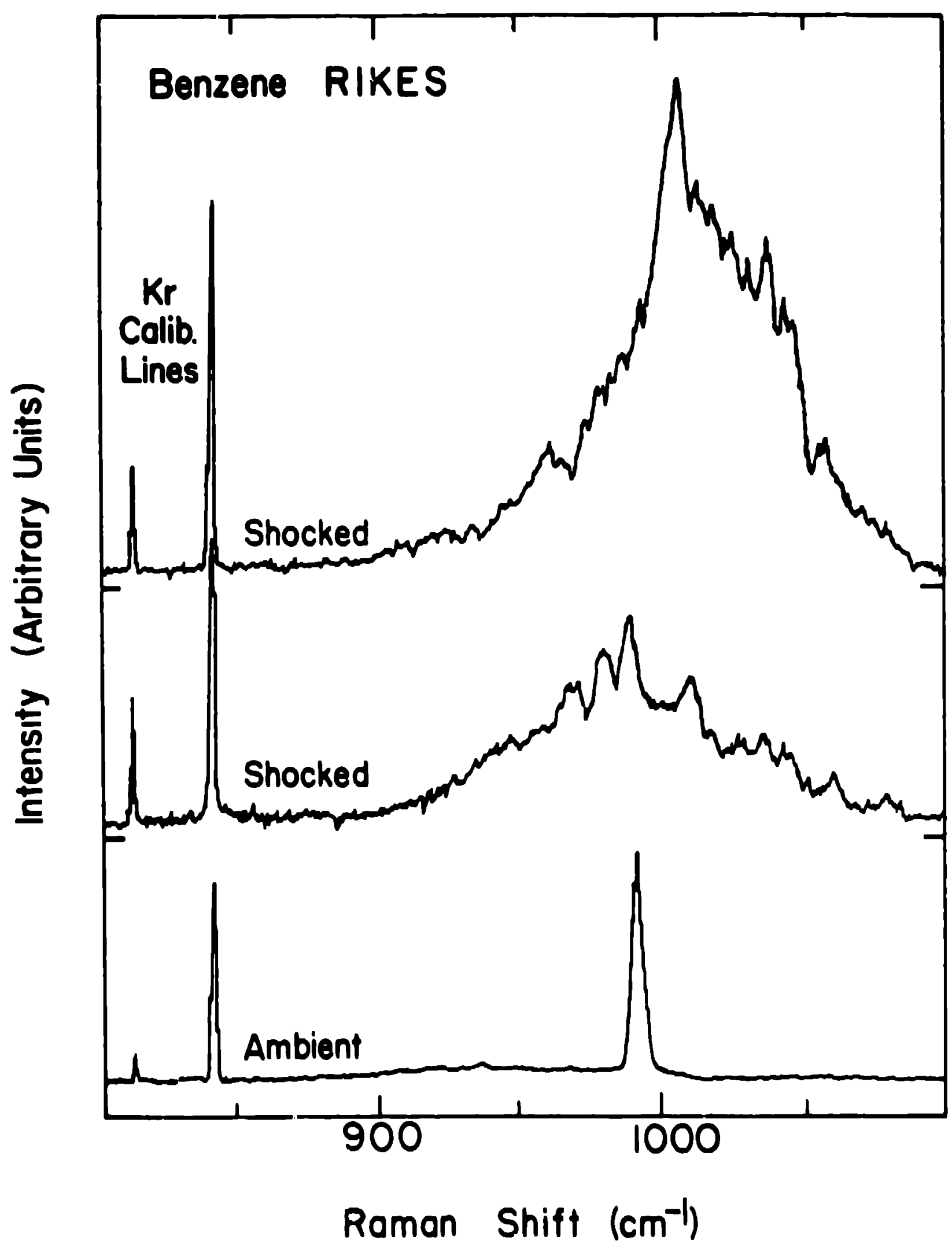


VIBRATIONAL MODES AND INFRARED SPECTRA (from Graener and Loubereau) $\mathrm{CH}_{2} \mathrm{Cl}_{2}$ $\mathrm{CH}_{2} \mathrm{Br}_{2}$

$\mathrm{CH}_{2} \mathrm{l}_{2}$

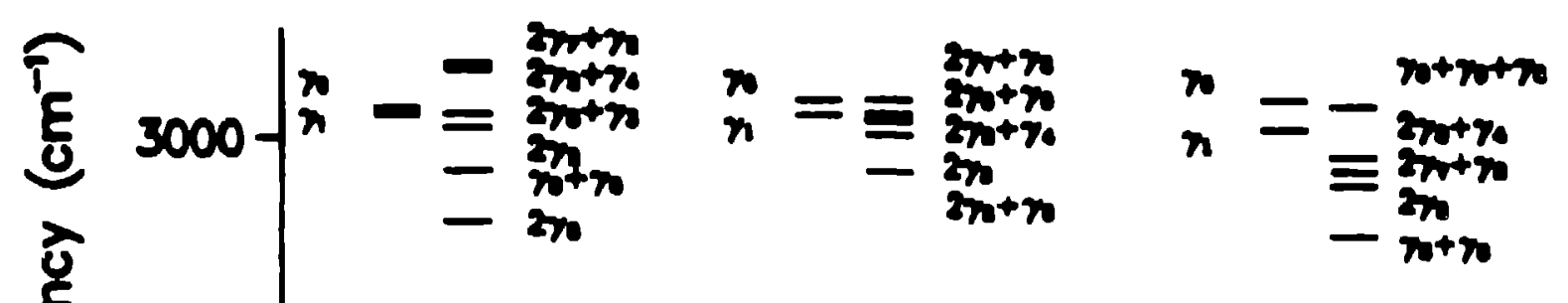
क्ष 2000

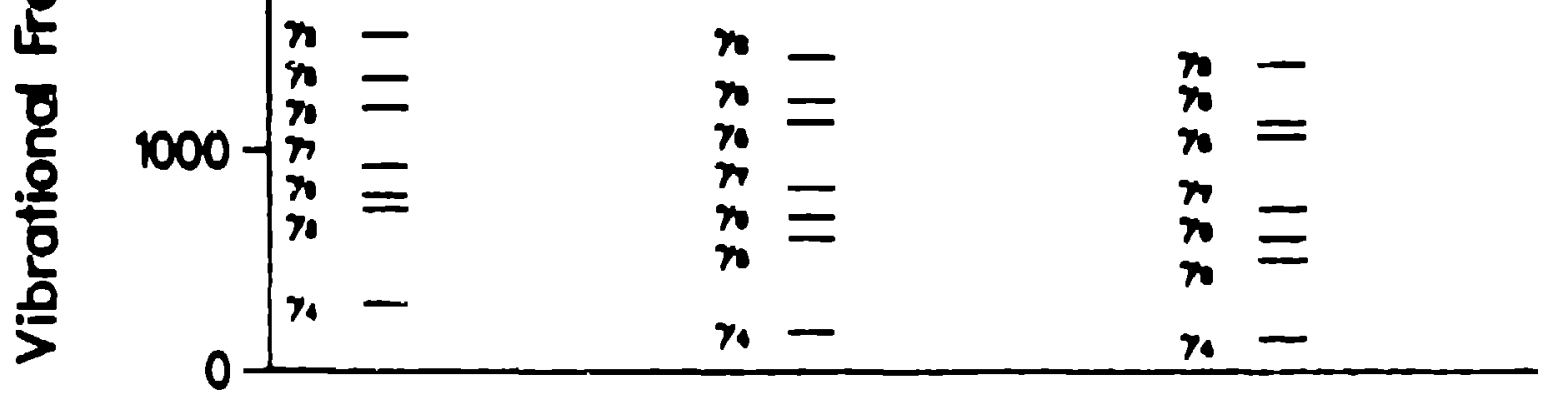
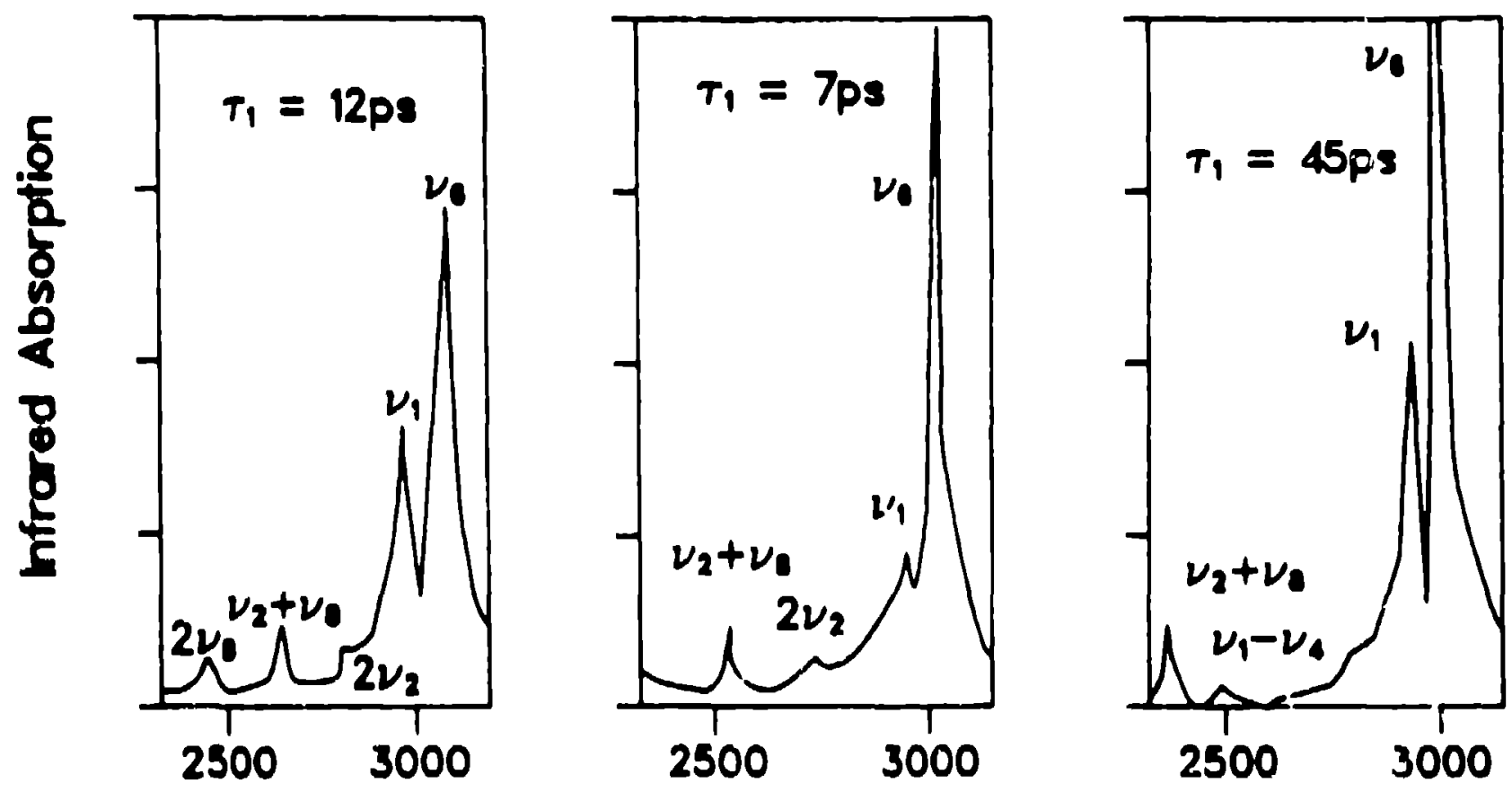


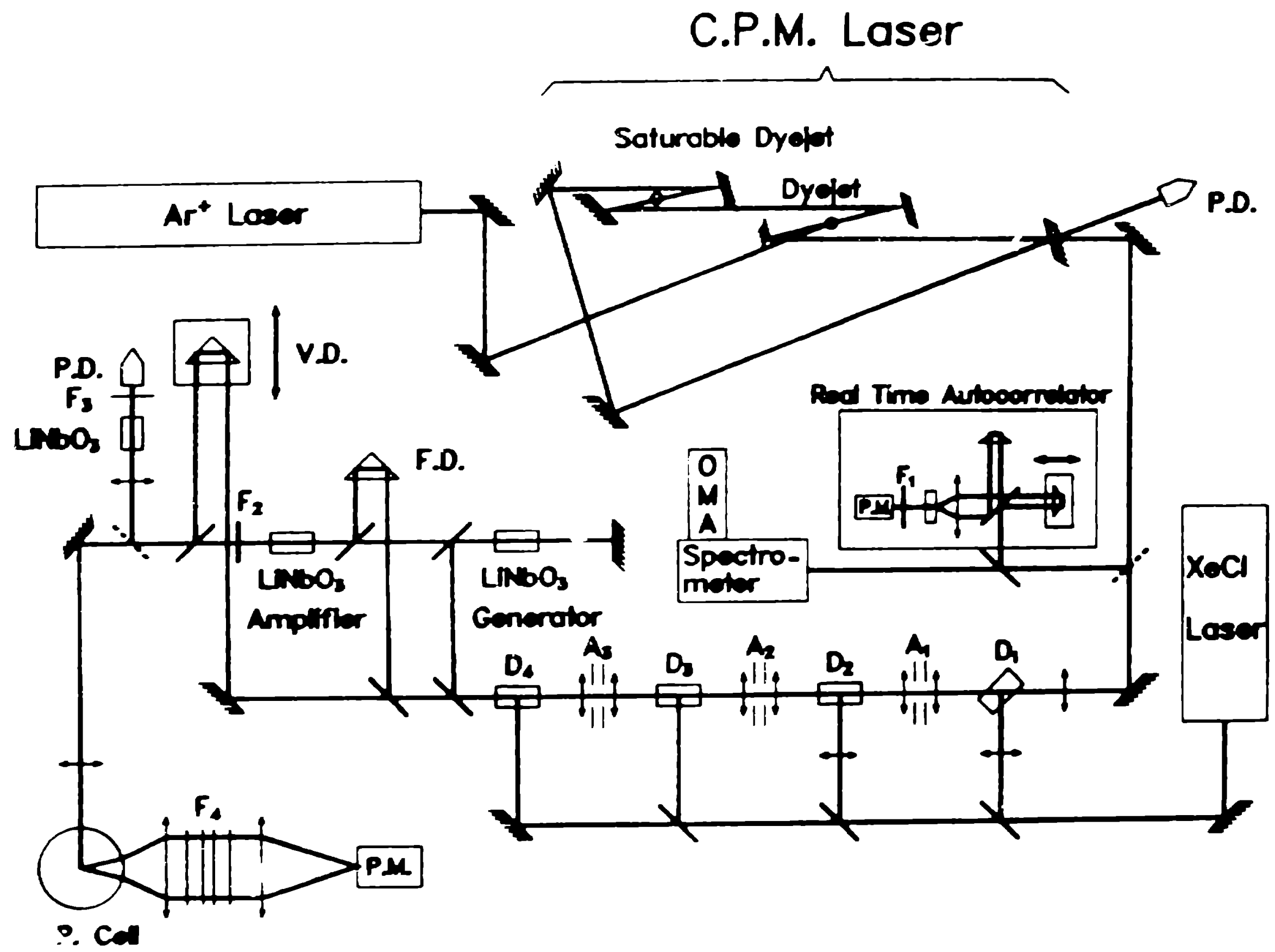

